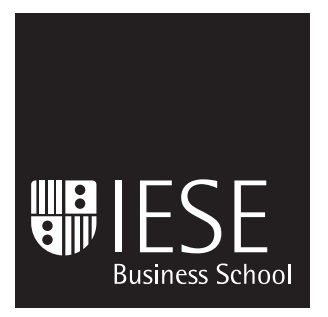

CIIF

Working Paper

WP no 451

January 2002

Rev. January 2006

University of Navarra

\title{
VALUING COMPANIES BY CASH FLOW DISCOUNTING: TEN METHODS AND NINE THEORIES
}

\author{
Pablo Fernández
}


The CIIF, International Center for Financial Research, is an interdisciplinary center with an international outlook and a focus on teaching and research in finance. It was created at the beginning of 1992 to channel the financial research interests of a multidisciplinary group of professors at IESE Business School and has established itself as a nucleus of study within the School's activities.

Ten years on, our chief objectives remain the same:

- Find answers to the questions that confront the owners and managers of finance companies and the financial directors of all kinds of companies in the performance of their duties

- Develop new tools for financial management

- Study in depth the changes that occur in the market and their effects on the financial dimension of business activity

All of these activities are programmed and carried out with the support of our sponsoring companies. Apart from providing vital financial assistance, our sponsors also help to define the Center's research projects, ensuring their practical relevance.

The companies in question, to which we reiterate our thanks, are:

Aena, A.T. Kearney, Caja Madrid, Fundación Ramón Areces, Grupo Endesa, Royal Bank of Scotland and Unión Fenosa.

http://www.iese.edu/ciif/ 


\title{
VALUING COMPANIES BY CASH FLOW DISCOUNTING: TEN METHODS AND NINE THEORIES
}

\author{
Pablo Fernández ${ }^{*}$
}

\section{Abstract}

This paper is a summarized compendium of all the methods and theories on company valuation using discounted cash flows. It illustrates ten methods: free cash flow; equity cash flow; capital cash flow; APV (adjusted present value); business's risk-adjusted free cash flow and equity cash flow; risk-free rate-adjusted free cash flow and equity cash flow; economic profit; and EVA.

All ten methods always give the same value. This result is logical, as all the methods analyze the same reality under the same hypotheses; they differ only in the cash flows taken as the starting point for the valuation.

The differences between the various theories of firm valuation arise from the calculation of the value of the tax shields (VTS). The paper illustrates and analyses nine different theories of the calculation of the VTS, and lists the most important valuation equations according to each of these theories.

* Professor, Financial Management, PricewaterhouseCoopers Chair of Finance, IESE

JEL Classification: G12, G31, M21

Keywords: Discounted Cash Flows, APV, WACC, Equity Cash Flow. 


\section{VALUING COMPANIES BY CASH FLOW DISCOUNTING: TEN METHODS AND NINE THEORIES ${ }^{*}$}

This paper is a summarized compendium of all the methods and theories on company valuation using discounted cash flows.

Section 1 shows the ten most commonly used methods for valuing companies by discounted cash flows:

1) Free cash flow discounted at the WACC;

2) Equity cash flows discounted at the required return on equity;

3) Capital cash flows discounted at the WACC before tax;

4) APV (adjusted present value);

5) The business's risk-adjusted free cash flows discounted at the required return on assets;

6) The business's risk-adjusted equity cash flows discounted at the required return on assets;

7) Economic profit discounted at the required return on equity;

8) EVA discounted at the WACC;

9) The risk-free rate-adjusted free cash flows discounted at the risk-free rate; and

10) The risk-free rate-adjusted equity cash flows discounted at the required return on assets.

All ten methods always give the same value. This result is logical, since all the methods analyze the same reality under the same hypotheses; they differ only in the cash flows taken as the starting point for the valuation. The tax shield of a given year is D Kd T. D is the value of debt, $\mathrm{Kd}$ is the required return on debt, and $\mathrm{T}$ is the corporate tax rate. $\mathrm{D} \mathrm{Kd}$ are the interest paid in a given year. The formulas used in the paper are valid if the interest rate on the debt matches the required return on debt $(\mathrm{Kd})$, or to put it another way, if the debt's market value is identical to its book value. The formulas for when this is not the case, are given in Appendix 3.

\footnotetext{
I would like to thank my colleagues José Manuel Campa and Charles Porter for their wonderful help revising earlier manuscripts of this paper, and an anonymous referee for very helpful comments. I would also like to thank Rafael Termes and my colleagues at IESE for their sharp questions that encouraged me to explore valuation problems.
} 
In Section 2, the ten methods and nine theories are applied to an example. The nine theories are:

1) Fernández (2004). Assumes that there are no leverage costs and that the risk of increases in debt is equal to the risk of the free cash flow.

2) Damodaran (1994). To introduce leverage costs, Damodaran assumes that the relationship between the levered and unlevered beta is: $\beta_{\mathrm{L}}=\mathrm{Bu}+\mathrm{D}(1-\mathrm{T}) \mathrm{Bu} / \mathrm{E}$ (instead of the relationship obtained in Fernández (2004), $\left.\beta_{L}=\beta u+D(1-T)(\beta u-\beta d) / E\right)$.

3) Practitioners' method. To introduce higher leverage costs, this method assumes that the relationship between the levered and unlevered beta is: $\beta_{L}=\beta u+D ~ B u / E$.

4) Harris and Pringle (1985) and Ruback (1995). These theories assume that the leveragedriven value creation or value of tax shields (VTS) is the present value of the tax shields (D Kd T) discounted at the required return on the unlevered equity $(\mathrm{Ku})$. According to them, VTS $=$ PV[D Kd T ; Ku].

5) Myers (1974), who assumes that the value of tax shields (VTS) is the present value of the tax shields discounted at the required return on debt (Kd). According to Myers, VTS $=\mathrm{PV}[\mathrm{D} \mathrm{Kd} \mathrm{T} ; \mathrm{Kd}]$.

6) Miles and Ezzell (1980). This theory states that the correct rate for discounting the tax shield (D Kd T) is Kd for the first year, and Ku for the following years.

7) Miller (1977) concludes that the leverage-driven value creation or value of the tax shields is zero.

8) With-cost-of leverage. This theory assumes that the cost of leverage is the present value of the interest differential that the company pays over the risk-free rate.

9) Modigliani and Miller (1963) calculate the value of tax shields by discounting the present value of the tax savings due to interest payments of a risk-free debt (T D $R_{F}$ ) at the risk-free rate $\left(\mathrm{R}_{\mathrm{F}}\right)$. Modigliani and Miller claim that:

$$
\mathrm{VTS}=\mathrm{PV}\left[\mathrm{R}_{\mathrm{F}} ; \mathrm{DT} \mathrm{R}_{\mathrm{F}}\right]
$$

Appendix 1 gives a brief overview of the most significant theories on discounted cash flow valuation.

Appendix 2 contains the valuation equations according to these theories.

Appendix 3 shows how the valuation equations change if the debt's market value is not equal to its nominal value.

Appendix 4 contains a list of the abbreviations used in the paper.

\section{Ten Discounted Cash Flow Methods for Valuing Companies}

There are four basic methods for valuing companies by discounted cash flows:

Method 1. Using the free cash flow and the WACC (weighted average cost of capital). 
Equation [1] indicates that the value of the debt (D) plus that of the shareholders' equity (E) is the present value of the expected free cash flows (FCF) that the company will generate, discounted at the weighted average cost of debt and shareholders' equity after tax (WACC):

$$
[1] \mathrm{E}_{0}+\mathrm{D}_{0}=\mathrm{PV}_{0}\left[\mathrm{WACC}_{\mathrm{t}} ; \mathrm{FCF}_{\mathrm{t}}\right]
$$

The definition of WACC or "weighted average cost of capital" is given by [2]:

$$
\text { [2] } \mathrm{WACC}_{\mathrm{t}}=\left[\mathrm{E}_{\mathrm{t}-1} \mathrm{Ke}_{\mathrm{t}}+\mathrm{D}_{\mathrm{t}-1} \mathrm{Kd}_{\mathrm{t}}(1-\mathrm{T})\right] /\left[\mathrm{E}_{\mathrm{t}-1}+\mathrm{D}_{\mathrm{t}-1}\right]
$$

$\mathrm{Ke}$ is the required return on equity, $\mathrm{Kd}$ is the cost of the debt, and $\mathrm{T}$ is the effective tax rate applied to earnings. $\mathrm{E}_{\mathrm{t}-1}+\mathrm{D}_{\mathrm{t}-1}$ are market values. In actual fact, "market values" are the values obtained when the valuation is performed using formula [1]. Consequently, the valuation is an iterative process: The free cash flows are discounted at the WACC to calculate the company's value $(D+E)$, but in order to obtain the WACC we need to know the company's value $(D+E)$.

Method 2. Using the expected equity cash flow (ECF) and the required return on equity (Ke).

Equation [3] indicates that the value of the equity (E) is the present value of the expected equity cash flows (ECF) discounted at the required return on equity (Ke).

$$
\text { [3] } \mathrm{E}_{0}=\mathrm{PV}_{0}\left[\mathrm{Ke}_{t} ; \mathrm{ECF}_{\mathrm{t}}\right]
$$

Equation [4] indicates that the value of the debt (D) is the present value of the expected debt cash flows (CFd) discounted at the required return on debt $(\mathrm{Kd})$.

$$
\text { [4] } \mathrm{D}_{0}=\mathrm{PV}_{0}\left[\mathrm{Kd}_{\mathrm{t}} ; \mathrm{CFd}_{\mathrm{t}}\right]
$$

The expression that relates the FCF with the ECF is:

$$
\text { [5] } \mathrm{ECF}_{\mathrm{t}}=\mathrm{FCF}_{\mathrm{t}}+\Delta \mathrm{D}_{\mathrm{t}}-\mathrm{I}_{\mathrm{t}}(1-\mathrm{T})
$$

$\Delta \mathrm{D}_{\mathrm{t}}$ is the increase in debt, and $\mathrm{I}_{\mathrm{t}}$ is the interest paid by the company. It is obvious that $C F d_{t}=I_{t}$ - $\Delta \mathrm{D}_{\mathrm{t}}$. Obviously, the free cash flow is the hypothetical equity cash flow when the company has no debt.

The sum of the values given by equations [3] and [4] is identical to the value provided by [1]:

$\mathrm{E}_{0}+\mathrm{D}_{0}=\mathrm{PV}_{0}\left[\mathrm{WACC}_{t} ; \mathrm{FCF}_{\mathrm{t}}\right]=\mathrm{PV}_{0}\left[\mathrm{Ke}_{\mathrm{t}} ; \mathrm{ECF}_{\mathrm{t}}\right]+\mathrm{PV}_{0}\left[\mathrm{Kd}_{\mathrm{t}} ; \mathrm{CFd}_{\mathrm{t}}\right]$. Indeed, one way of defining the WACC is: The WACC is the rate at which the FCF must be discounted so that equation [2] gives the same result as that given by the sum of [3] and [4].

Method 3. Using the capital cash flow (CCF) and the $W_{A C C_{B T}}$ (weighted average cost of capital, before tax).

Arditti and Levy (1977) suggested that the firm's value could be calculated by discounting the capital cash flows instead of the free cash flow. The capital cash flows are the cash flows available for all holders of the company's securities, whether these be debt or shares, and are equivalent to the equity cash flow (ECF) plus the cash flow corresponding to the debt holders (CFd). 
Equation [6] indicates that the value of the debt today (D) plus that of the shareholders' equity (E) is equal to the capital cash flow (CCF) discounted at the weighted average cost of debt and shareholders' equity before tax (WACC $\left.\mathrm{BT}_{\mathrm{BT}}\right)$.

$$
[6] \mathrm{E}_{0}+\mathrm{D}_{0}=\mathrm{PV}\left[\mathrm{WACC} \mathrm{BTt}_{\mathrm{t}} ; \mathrm{CCF}_{\mathrm{t}}\right]
$$

The definition of $\mathrm{WACC}_{\mathrm{BT}}$ is [7]:

$$
\text { [7] } \mathrm{WACC}_{\mathrm{BT} \mathrm{t}}=\left[\mathrm{E}_{\mathrm{t}-1} \mathrm{Ke}_{\mathrm{t}}+\mathrm{D}_{\mathrm{t}-1} \mathrm{Kd}_{\mathrm{t}}\right] /\left[\mathrm{E}_{\mathrm{t}-1}+\mathrm{D}_{\mathrm{t}-1}\right]
$$

Expression [7] is obtained by making [1] equal to [6]. $\mathrm{WACC}_{\mathrm{BT}}$ represents the discount rate that ensures that the value of the company obtained using the two expressions is the same:

$\mathrm{E}_{0}+\mathrm{D}_{0}=\mathrm{PV}\left[\mathrm{WACC}_{\mathrm{BTt}} ; \mathrm{CCF}_{\mathrm{t}}\right]=\mathrm{PV}\left[\mathrm{WACC}_{\mathrm{t}} ; \mathrm{FCF}_{\mathrm{t}}\right]$

One way of defining the $\mathrm{WACC}_{\mathrm{BT}}$ is: the $\mathrm{WACC}_{\mathrm{BT}}$ is the rate at which the CCF must be discounted so that equation [6] gives the same result as that given by the sum of [3] and [4].

The expression that relates the CCF with the ECF and the FCF is [8]:

$$
[8] \mathrm{CCFt}=\mathrm{ECFt}+\mathrm{CFdt}=\mathrm{ECFt}-\Delta \mathrm{Dt}+\mathrm{It}=\mathrm{FCFt}+\mathrm{It} \mathrm{T}
$$

$\Delta \mathrm{Dt}=\mathrm{Dt}-\mathrm{Dt}-1 ; \quad \mathrm{It}=\mathrm{Dt}-1 \mathrm{Kdt}$

\section{Method 4. Adjusted present value (APV)}

The adjusted present value (APV) in equation [9] indicates that the value of the debt (D) plus that of the shareholders' equity (E) is equal to the value of the unlevered company's shareholders' equity, $\mathrm{Vu}$, plus the present value of the value of the tax shield (VTS):

[9] $\mathrm{E}_{0}+\mathrm{D}_{0}=\mathrm{Vu}_{0}+\mathrm{VTS}_{0}$

We can see in Appendices 1 and 2 that there are several theories for calculating the VTS.

If $\mathrm{Ku}$ is the required return on equity in the debt-free company (also called the required return on assets), $\mathrm{Vu}$ is given by [10]:

$$
\text { [10] } \mathrm{Vu}_{0}=\mathrm{PV}_{0}\left[\mathrm{Ku}_{\mathrm{t}} ; \mathrm{FCF}_{\mathrm{t}}\right]
$$

Consequently, $\mathrm{VTS}_{0}=\mathrm{E}_{0}+\mathrm{D}_{0}-\mathrm{Vu}_{0}=\mathrm{PV}_{0}\left[\mathrm{WACC}_{\mathrm{t}} ; \mathrm{FCF}_{\mathrm{t}}\right]-\mathrm{PV}_{0}\left[\mathrm{Ku}_{\mathrm{t}} ; \mathrm{FCF}_{\mathrm{t}}\right]$

We can talk of a fifth method (using the business risk-adjusted free cash flow), although this is not actually a new method but is derived from the previous methods:

Method 5. Using the business risk-adjusted free cash flow and Ku (required return on assets).

Equation [11] indicates that the value of the debt (D) plus that of the shareholders' equity (E) is the present value of the expected business risk-adjusted free cash flows (FCF $\mid \mathrm{Ku}$ ) that will be generated by the company, discounted at the required return on assets $(\mathrm{Ku})$ :

$[11] \mathrm{E}_{0}+\mathrm{D}_{0}=\mathrm{PV}_{0}\left[\mathrm{Ku}_{\mathrm{t}} ; \mathrm{FCF}_{\mathrm{t}}|| \mathrm{Ku}\right]$

The definition of the business risk-adjusted free cash flows (FCF || $\mathrm{Ku})$ is [12]:

[12] $\mathrm{FCF}_{\mathrm{t}} \| \mathrm{Ku}=\mathrm{FCF}_{\mathrm{t}}-\left(\mathrm{E}_{\mathrm{t}-1}+\mathrm{D}_{\mathrm{t}-1}\right)\left[\mathrm{WACC}_{\mathrm{t}}-\mathrm{Ku}_{\mathrm{t}}\right]$

Expression [12] is obtained by making [11] equal to [1]. 
Likewise, we can talk of a sixth method (using the business risk-adjusted equity cash flow), although this is not actually a new method, but is derived from the previous methods:

Method 6. Using the business risk-adjusted equity cash flow and Ku (required return on assets).

Equation [13] indicates that the value of the equity (E) is the present value of the expected business risk-adjusted equity cash flows $(\mathrm{ECF}|| \mathrm{Ku})$ discounted at the required return on assets $(\mathrm{Ku})$ :

$[13] \mathrm{E}_{0}=\mathrm{PV}_{0}\left[\mathrm{Ku}_{\mathrm{t}} ; \mathrm{ECF}_{\mathrm{t}} \| \mathrm{Ku}\right]$

The definition of the business risk-adjusted equity cash flows $(\mathrm{ECF}|| \mathrm{Ku})$ is [14]:

[14] $\mathrm{ECF}_{\mathrm{t}}|| \mathrm{Ku}=\mathrm{ECF}_{\mathrm{t}}-\mathrm{E}_{\mathrm{t}-1}\left[\mathrm{Ke}_{\mathrm{t}}-\mathrm{Ku}_{\mathrm{t}}\right]$

Expression [14] is obtained by making [13] equal to [3].

Method 7. Using the economic profit and Ke (required return on equity).

Equation [15] indicates that the value of the equity (E) is the equity's book value plus the present value of the expected economic profit (EP) discounted at the required return on equity (Ke).

$[15] \mathrm{E}_{0}=\mathrm{Ebv}_{0}+\mathrm{PV}_{0}\left[\mathrm{Ke}_{\mathrm{t}} ; \mathrm{EP}_{\mathrm{t}}\right]$

The term economic profit (EP) is used to define the accounting net income or profit after tax (PAT) less the equity's book value $\left(\mathrm{Ebv}_{\mathrm{t}-1}\right)$ multiplied by the required return on equity.

[16] $\mathrm{EP}_{\mathrm{t}}=\mathrm{PAT}_{\mathrm{t}}-\mathrm{Ke} \mathrm{Ebv}_{\mathrm{t}-1}$

Method 8. Using the EVA (economic value added) and the WACC (weighted average cost of capital).

Equation [17] indicates that the value of the debt (D) plus that of the shareholders' equity (E) is the book value of the shareholders' equity and the debt $\left(\mathrm{Ebv}_{0}+\mathrm{N}_{0}\right)$ plus the present value of the expected EVA, discounted at the weighted average cost of capital (WACC):

$[17] \mathrm{E}_{0}+\mathrm{D}_{0}=\left(\mathrm{Ebv}_{0}+\mathrm{N}_{0}\right)+\mathrm{PV}_{0}\left[\mathrm{WACC}_{\mathrm{t}} ; \mathrm{EVA}_{\mathrm{t}}\right]$

The EVA (economic value added) is the NOPAT (net operating profit after tax) less the company's book value $\left(\mathrm{D}_{\mathrm{t}-1}+\mathrm{Ebv}_{\mathrm{t}-1}\right)$ multiplied by the weighted average cost of capital (WACC). The NOPAT is the profit of the unlevered company (debt-free).

[18] $\mathrm{EVA}_{\mathrm{t}}=\mathrm{NOPAT}_{\mathrm{t}}-\left(\mathrm{D}_{\mathrm{t}-1}+\mathrm{Ebv}_{\mathrm{t}-1}\right) \mathrm{WACC}_{\mathrm{t}}$

Method 9. Using the risk-free-adjusted free cash flows discounted at the risk-free rate

Equation [19] indicates that the value of the debt (D) plus that of the shareholders' equity (E) is the present value of the expected risk-free-adjusted free cash flows $\left(F C F \| R_{F}\right.$ ) that will be generated by the company, discounted at the risk-free rate $\left(\mathrm{R}_{\mathrm{F}}\right)$ :

$[19] \mathrm{E}_{0}+\mathrm{D}_{0}=\mathrm{PV}_{0}\left[\mathrm{R}_{\mathrm{Ft}} ; F C F_{\mathrm{t}}|| \mathrm{R}_{\mathrm{F}}\right]$

The definition of the risk-free-adjusted free cash flows $\left(\mathrm{FCF}|| \mathrm{R}_{\mathrm{F}}\right)$ is $[20]$ :

[20] $\mathrm{FCF}_{\mathrm{t}}|| \mathrm{R}_{\mathrm{F}}=\mathrm{FCF}_{\mathrm{t}}-\left(\mathrm{E}_{\mathrm{t}-1}+\mathrm{D}_{\mathrm{t}-1}\right)\left[\mathrm{WACC}_{\mathrm{t}}-\mathrm{R}_{\mathrm{F}}\right]$ 
Expression [20] is obtained by making [19] equal to [1].

Likewise, we can talk of a tenth method (using the risk-free-adjusted equity cash flow), although this is not actually a new method but is derived from the previous methods:

Method 10. Using the risk-free-adjusted equity cash flows discounted at the risk-free rate

Equation [21] indicates that the value of the equity $(\mathrm{E})$ is the present value of the expected riskfree-adjusted equity cash flows $\left(E C F|| R_{F}\right)$ discounted at the risk-free rate $\left(R_{F}\right)$ :

[21] $\mathrm{E}_{0}=\mathrm{PV}_{0}\left[\mathrm{R}_{\mathrm{Ft}} ; \mathrm{ECF}_{\mathrm{t}} \| \mathrm{R}_{\mathrm{F}}\right]$

The definition of the risk-free-adjusted equity cash flows $\left(E C F|| R_{F}\right)$ is [22]:

[22] $\mathrm{ECF}_{\mathrm{t}}|| \mathrm{R}_{\mathrm{F}}=\mathrm{ECF}_{\mathrm{t}}-\mathrm{E}_{\mathrm{t}-1}\left[\mathrm{Ke}_{\mathrm{t}}-\mathrm{R}_{\mathrm{F}}\right]$

Expression [22] is obtained by making [21] equal to [3].

We could also talk of an eleventh method; using the business risk-adjusted capital cash flow and $\mathrm{Ku}$ (required return on assets), but the business risk-adjusted capital cash flow is identical to the business risk-adjusted free cash flow $(\mathrm{CCF}|| \mathrm{Ku}=\mathrm{FCF}|| \mathrm{Ku})$. Therefore, this method would be identical to Method 5.

We could also talk of a twelfth method; using the risk-free-adjusted capital cash flow and $R_{F}$ (risk-free rate), but the risk-free-adjusted capital cash flow is identical to the risk-free-adjusted free cash flow $\left(C C F|| R_{F}=F C F|| R_{F}\right)$. Therefore, this method would be identical to Method 9.

\section{An Example. Valuation of the Company Toro Inc.}

The company Toro Inc. has the balance sheet and income statement forecasts for the next few years shown in Table 1. After year 3, the balance sheet and the income statement are expected to grow at an annual rate of $2 \%$.

\section{Table 1}

Balance Sheet and Income Statement Forecasts for Toro Inc.

\begin{tabular}{|lrrrr|rr|}
\cline { 2 - 7 } \multicolumn{1}{c|}{} & $\mathbf{0}$ & $\mathbf{1}$ & $\mathbf{2}$ & $\mathbf{3}$ & $\mathbf{4}$ & $\mathbf{5}$ \\
\hline WCR (working capital requirements) & 400 & 430 & 515 & 550 & 561.00 & 572.22 \\
Gross fixed assets & 1,600 & 1,800 & 2,300 & 2,600 & $2,913.00$ & $3,232.26$ \\
- accumulated depreciation & & 200 & 450 & 720 & 995.40 & $1,276.31$ \\
Net fixed assets & 1,600 & 1,600 & 1,850 & 1,880 & $1,917.60$ & $1,955.95$ \\
TOTAL ASSETS & $\mathbf{2 , 0 0 0}$ & $\mathbf{2 , 0 3 0}$ & $\mathbf{2 , 3 6 5}$ & $\mathbf{2 , 4 3 0}$ & $\mathbf{2 , 4 7 8 . 6 0}$ & $\mathbf{2 , 5 2 8}$ \\
\hline & 1,500 & 1,500 & 1,500 & 1,500 & $1,530.00$ & $1,560.60$ \\
\hline Debt (N) & 500 & 530 & 865 & 930 & 948.60 & 967.57 \\
Equity (book value) & $\mathbf{2 , 0 0 0}$ & $\mathbf{2 , 0 3 0}$ & $\mathbf{2 , 3 6 5}$ & $\mathbf{2 , 4 3 0}$ & $\mathbf{2 , 4 7 8 . 6 0}$ & $\mathbf{2 , 5 2 8}$ \\
\hline
\end{tabular}

\section{Income statement}

\begin{tabular}{|llll|rr|}
\hline Margin & 420 & 680 & 740 & 765.00 & 780 \\
Interest payments & 120 & 120 & 120 & 120.00 & 122 \\
PBT (profit before tax) & 300 & 560 & 620 & 645.00 & 658 \\
Taxes & 105 & 196 & 217 & 225.75 & 230.27 \\
PAT (profit after tax = net income) & $\mathbf{1 9 5}$ & $\mathbf{3 6 4}$ & $\mathbf{4 0 3}$ & $\mathbf{4 1 9 . 2 5}$ & $\mathbf{4 2 7 . 6 4}$ \\
\hline
\end{tabular}


Using the balance sheet and income statement forecasts in Table 1, we can readily obtain the cash flows given in Table 2. Obviously, the cash flows grow at a rate of 2\% after year 4 .

\section{Table 2}

Cash Flow Forecasts for Toro Inc.

\begin{tabular}{|lrrr|rr|}
\hline & $\mathbf{1}$ & $\mathbf{2}$ & $\mathbf{3}$ & $\mathbf{4}$ & $\mathbf{5}$ \\
\cline { 2 - 6 } PAT (profit after tax) & $\mathbf{1 9 5}$ & $\mathbf{3 6 4}$ & $\mathbf{4 0 3}$ & $\mathbf{4 1 9 . 2 5}$ & $\mathbf{4 2 7 . 6 4}$ \\
\hline + depreciation & 200 & 250.00 & 270.00 & 275.40 & 280.91 \\
+ increase in debt & 0 & 0.00 & 0.00 & 30.00 & 30.60 \\
- increase in working capital requirements & -30 & -85 & -35 & -11 & -11.22 \\
- investment in fixed assets & -200 & -500.00 & -300.00 & -313.00 & -319.26 \\
ECF & $\mathbf{1 6 5 . 0 0}$ & $\mathbf{2 9 . 0 0}$ & $\mathbf{3 3 8 . 0 0}$ & $\mathbf{4 0 0 . 6 5}$ & $\mathbf{4 0 8 . 6 6}$ \\
\hline FCF & $\mathbf{2 4 3 . 0 0}$ & $\mathbf{1 0 7 . 0 0}$ & $\mathbf{4 1 6 . 0 0}$ & $\mathbf{4 4 8 . 6 5}$ & $\mathbf{4 5 7 . 6 2}$ \\
\hline CFd & $\mathbf{1 2 0 . 0 0}$ & $\mathbf{1 2 0 . 0 0}$ & $\mathbf{1 2 0 . 0 0}$ & $\mathbf{9 0 . 0 0}$ & $\mathbf{9 1 . 8 0}$ \\
\hline CCF & $\mathbf{2 8 5 . 0 0}$ & $\mathbf{1 4 9 . 0 0}$ & $\mathbf{4 5 8 . 0 0}$ & $\mathbf{4 9 0 . 6 5}$ & $\mathbf{5 0 0 . 4 6}$ \\
\hline
\end{tabular}

The unlevered beta $(\mathrm{Bu})$ is 1 . The risk-free rate is $6 \%$. The cost of debt is $8 \%$. The corporate tax rate is $35 \%$. The market risk premium is $4 \%$. Consequently, using the CAPM, the required return on assets is $10 \%$, because $\mathrm{Ku}=\mathrm{R}_{\mathrm{F}}+\mathrm{Bu} \mathrm{P}_{\mathrm{M}}=6 \%+4 \%=10 \%$. With these parameters, the valuation of this company's equity, using the above equations, is given in Table 3. The required return on equity $(\mathrm{Ke})$ appears in the second line of the table. The required return on equity $(\mathrm{Ke})$ has been calculated according to Fernández (2004) (see Appendix 1). Equation [3] enables the value of the equity to be obtained by discounting the equity cash flows at the required return on equity (Ke). Likewise, equation [4] enables the value of the debt to be obtained by discounting the debt cash flows at the required return on debt $(\mathrm{Kd})$. The value of the debt is equal to the nominal value (book value) given in Table 1 because we have considered that the required return on debt is equal to its cost (8\%). Another way to calculate the value of the equity is using equation [1]. The present value of the free cash flows discounted at the WACC (equation [2]) gives us the value of the company, which is the value of the debt plus that of the equity. By subtracting the value of the debt from this quantity, we obtain the value of the equity. Another way of calculating the value of the equity is using equation [6]. The present value of the capital cash flows discounted at the $\mathrm{WACC}_{\mathrm{BT}}$ (equation [7]) gives us the value of the company, which is the value of the debt plus that of the equity. By subtracting the value of the debt from this quantity, we obtain the value of the equity. The fourth method for calculating the value of the equity is using the adjusted present value, equation [9]. The value of the company is the sum of the value of the unlevered company (equation [10]) plus the present value of the value of the tax shield (VTS). As the required return on equity (Ke) has been calculated according to Fernández (2004), we must also calculate the VTS accordingly: $\mathrm{VTS}=\mathrm{PV}(\mathrm{Ku} ; \mathrm{D} \mathrm{T} \mathrm{Ku})$.

The business risk-adjusted equity cash flow and free cash flow (ECF $\mid \mathrm{Ku}$ and $\mathrm{FCF}|| \mathrm{Ku}$ ) are also calculated using equations [14] and [12]. Equation [13] enables us to obtain the value of the equity by discounting the business risk-adjusted equity cash flows at the required return on assets $(\mathrm{Ku})$. Another way to calculate the value of the equity is using equation [11]. The present value of the business risk-adjusted free cash flows discounted at the required return on assets $\mathrm{Ku})$ gives us the value of the company, which is the value of the debt plus that of the equity. By subtracting the value of the debt from this quantity, we obtain the value of the equity. 
The economic profit (EP) is calculated using equation [16]. Equation [15] indicates that the value of the equity (E) is the equity's book value plus the present value of the expected economic profit (EP) discounted at the required return on equity (Ke).

The EVA (economic value added) is calculated using equation [18]. Equation [17] indicates that the equity value (E) is the present value of the expected EVA discounted at the weighted average cost of capital (WACC), plus the book value of the equity and the debt $\left(\mathrm{Ebv}_{0}+\mathrm{N}_{0}\right)$ minus the value of the debt (D).

The risk-free-adjusted equity cash flow and free cash flow (ECF ||$R_{F}$ and $F C F|| R_{F}$ ) are also calculated using equations [22] and [20]. Equation [21] enables us to obtain the value of the equity by discounting the risk-free-adjusted equity cash flows at the risk-free rate $\left(\mathrm{R}_{\mathrm{F}}\right)$. Another way to calculate the value of the equity is using equation [19]. The present value of the riskfree-adjusted free cash flows discounted at the required return on assets $\left(\mathrm{R}_{\mathrm{F}}\right)$ gives us the value of the company, which is the value of the debt plus that of the equity. By subtracting the value of the debt from this quantity, we obtain the value of the equity.

Table 3 shows that the result obtained with all ten valuations is the same. The value of the equity today is $3,958.96$. As we have already mentioned, these valuations have been performed according to the Fernández (2004) theory. The valuations performed using other theories are discussed further on.

\section{Table 3}

Valuation of Toro Inc. No Cost of Leverage

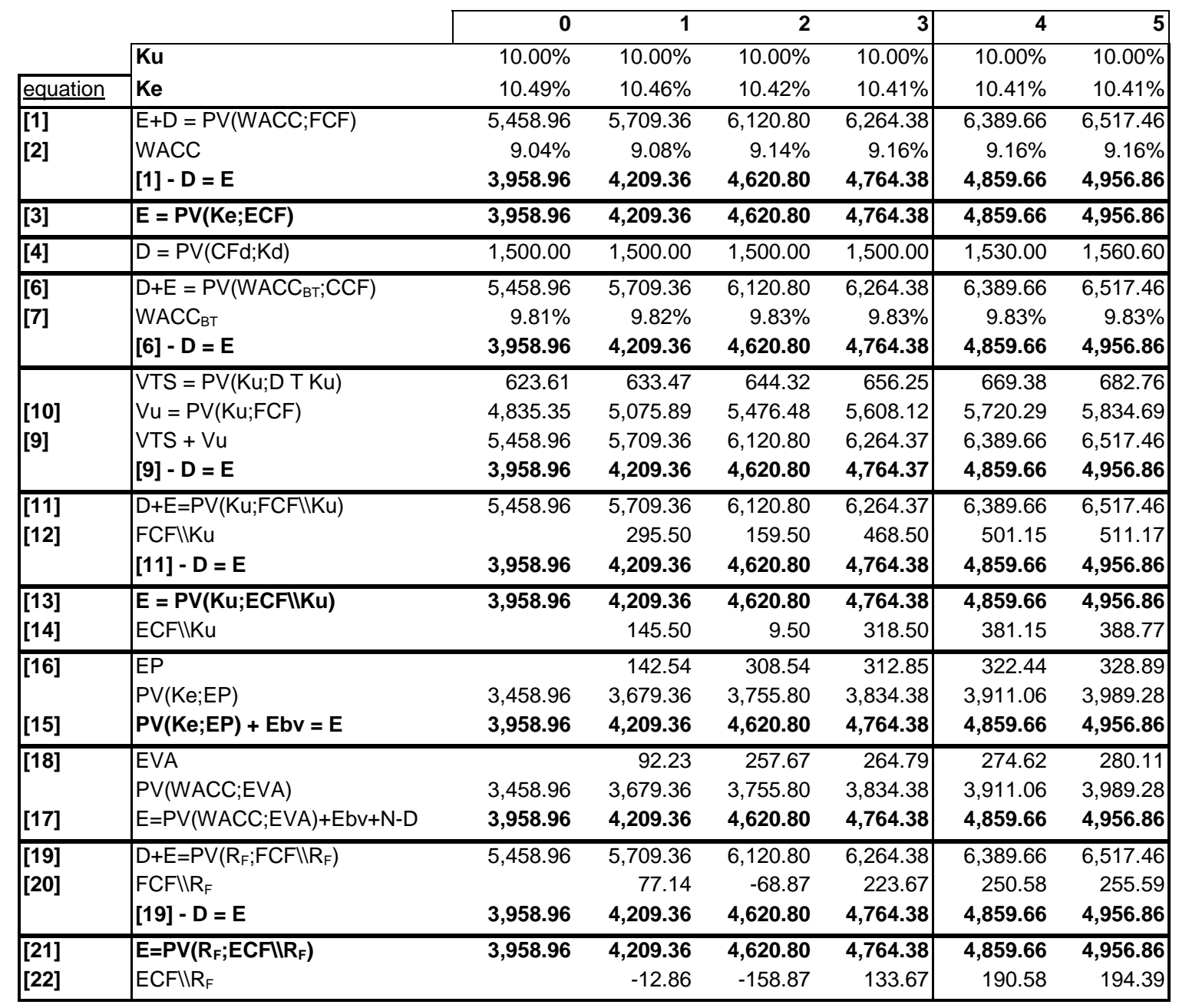


Tables 4 to 11 contain the most salient results of the valuation performed on the company Toro Inc. according to Damodaran (1994), Practitioners' method, Harris and Pringle (1985), Myers (1974), Miles and Ezzell (1980), Miller (1977), With-cost-of-leverage theory, and Modigliani and Miller (1963).

\section{Table 4}

Valuation of Toro Inc. According to Damodaran (1994)

\begin{tabular}{|c|c|c|c|c|c|c|}
\hline & 0 & 1 & 2 & 3 & 4 & 5 \\
\hline VTS = PV[Ku; DTKu - D (Kd- $\left.\left.R_{F}\right)(1-T)\right]$ & 391.98 & 398.18 & 405.00 & 412.50 & 420.75 & 429.16 \\
\hline$\beta_{\mathrm{L}}$ & 1.261581 & 1.245340 & 1.222528 & 1.215678 & 1.215678 & 1.215678 \\
\hline $\mathrm{Ke}$ & $11.05 \%$ & $10.98 \%$ & $10.89 \%$ & $10.86 \%$ & $10.86 \%$ & $10.86 \%$ \\
\hline E & $3,727.34$ & $3,974.07$ & $4,381.48$ & $4,520.62$ & $4,611.04$ & $4,703.26$ \\
\hline WACC & $9.369 \%$ & $9.397 \%$ & $9.439 \%$ & $9.452 \%$ & $9.452 \%$ & $9.452 \%$ \\
\hline WACC $_{\mathrm{BT}}$ & $10.172 \%$ & $10.164 \%$ & $10.153 \%$ & $10.149 \%$ & $10.149 \%$ & $10.149 \%$ \\
\hline$E+D$ & $5,227.34$ & $5,474.07$ & $5,881.48$ & $6,020.63$ & $6,141.04$ & $6,263.86$ \\
\hline EVA & & 85.63 & 251.24 & 257.77 & 267.57 & 272.92 \\
\hline EP & & 139.77 & 305.80 & 308.80 & 318.23 & 324.59 \\
\hline ECF $\backslash \backslash \mathrm{Ku}$ & & 126.00 & -10.00 & 299.00 & 361.65 & 368.88 \\
\hline FCF $\mid \backslash K u$ & & 276.00 & 140.00 & 449.00 & 481.65 & 491.28 \\
\hline$E C F \backslash \backslash R_{F}$ & & -23.09 & -168.96 & 123.74 & 180.83 & 184.44 \\
\hline$F C F \backslash \backslash R_{F}$ & & 66.91 & -78.96 & 213.74 & 240.83 & 245.64 \\
\hline
\end{tabular}

\section{Table 5}

Valuation of Toro Inc. According to the Practitioners' Method

\begin{tabular}{|c|c|c|c|c|c|c|}
\hline & 0 & 1 & 2 & 3 & 4 & 5 \\
\hline $\mathrm{VTS}=\mathrm{PV}\left[\mathrm{Ku} ; \mathrm{T} \mathrm{D} \mathrm{Kd}-\mathrm{D}\left(\mathrm{Kd}-\mathrm{R}_{\mathrm{F}}\right)\right]$ & 142.54 & 144.79 & 147.27 & 150.00 & 153.00 & 156.06 \\
\hline$\beta_{\mathrm{L}}$ & 1.431296 & 1.403152 & 1.363747 & 1.352268 & 1.352268 & 1.352268 \\
\hline $\mathrm{Ke}$ & $11.73 \%$ & $11.61 \%$ & $11.45 \%$ & $11.41 \%$ & $11.41 \%$ & $11.41 \%$ \\
\hline E & $3,477.89$ & $3,720.68$ & $4,123.75$ & $4,258.13$ & $4,343.29$ & $4,430.15$ \\
\hline WACC & $9.759 \%$ & $9.770 \%$ & $9.787 \%$ & $9.792 \%$ & $9.792 \%$ & $9.792 \%$ \\
\hline WACC $_{\mathrm{BT}}$ & $10.603 \%$ & $10.575 \%$ & $10.533 \%$ & $10.521 \%$ & $10.521 \%$ & $10.521 \%$ \\
\hline$E+D$ & $4,977.89$ & $5,220.68$ & $5,623.75$ & $5,758.13$ & $5,873.29$ & $5,990.75$ \\
\hline EVA & & 77.82 & 243.67 & 249.55 & 259.31 & 264.50 \\
\hline EP & & 136.37 & 302.45 & 303.91 & 313.15 & 319.41 \\
\hline ECFI\Ku & & 105.00 & -31.00 & 278.00 & 340.65 & 347.46 \\
\hline FCF $\backslash \backslash \mathrm{Ku}$ & & 255.00 & 119.00 & 428.00 & 460.65 & 469.86 \\
\hline$E C F \backslash \backslash R_{F}$ & & -34.12 & -179.83 & 113.05 & 170.33 & 173.73 \\
\hline$F C F \backslash \backslash R_{F}$ & & 55.88 & -89.83 & 203.05 & 230.33 & 234.93 \\
\hline
\end{tabular}




\section{Table 6}

Valuation of Toro Inc. According to Harris and Pringle (1985), and Ruback (1995)

\begin{tabular}{|c|c|c|c|c|c|c|}
\hline & 0 & 1 & 2 & 3 & 4 & 5 \\
\hline VTS = PV[Ku; T D Kd] & 498.89 & 506.78 & 515.45 & 525.00 & 535.50 & 546.21 \\
\hline$\beta_{\mathrm{L}}$ & 1.195606 & 1.183704 & 1.166966 & 1.161878 & 1.161878 & 1.161878 \\
\hline $\mathrm{Ke}$ & $10.78 \%$ & $10.73 \%$ & $10.67 \%$ & $10.65 \%$ & $10.65 \%$ & $10.65 \%$ \\
\hline E & $3,834.24$ & $4,082.67$ & $4,491.93$ & $4,633.12$ & $4,725.79$ & $4,820.30$ \\
\hline WACC & $9.213 \%$ & $9.248 \%$ & $9.299 \%$ & $9.315 \%$ & $9.315 \%$ & $9.315 \%$ \\
\hline $\mathrm{WACC}_{\mathrm{BT}}=\mathrm{Ku}$ & $10.000 \%$ & $10.000 \%$ & $10.000 \%$ & $10.000 \%$ & $10.000 \%$ & $10.000 \%$ \\
\hline$E+D$ & $5,334.24$ & $5,582.67$ & $5,991.93$ & $6,133.12$ & $6,255.79$ & $6,380.90$ \\
\hline EVA & & 88.75 & 254.27 & 261.08 & 270.89 & 276.31 \\
\hline EP & & 141.09 & 307.11 & 310.72 & 320.23 & 326.63 \\
\hline$E C F \backslash \backslash K u$ & & 135.00 & -1.00 & 308.00 & 370.65 & 378.06 \\
\hline FCFI\Ku & & 285.00 & 149.00 & 458.00 & 490.65 & 500.46 \\
\hline$E C F \backslash \backslash R_{F}$ & & -18.37 & -164.31 & 128.32 & 185.33 & 189.03 \\
\hline $\mathrm{FCF} \backslash \backslash \mathrm{R}_{\mathrm{F}}$ & & 71.63 & -74.31 & 218.32 & 245.33 & 250.23 \\
\hline
\end{tabular}

\section{Table 7}

Valuation of Toro Inc. According to Myers (1974)

\begin{tabular}{|c|c|c|c|c|c|c|}
\hline & 0 & 1 & 2 & 3 & 4 & 5 \\
\hline $\mathrm{VTS}=\mathrm{PV}(\mathrm{Kd} ; \mathrm{D} \mathrm{Kd} \mathrm{T})$ & 663.92 & 675.03 & 687.04 & 700.00 & 714.00 & 728.28 \\
\hline$\beta_{\mathrm{L}}$ & 1.104529 & 1.097034 & 1.087162 & 1.083193 & 1.083193 & 1.083193 \\
\hline $\mathrm{Ke}$ & $10.42 \%$ & $10.39 \%$ & $10.35 \%$ & $10.33 \%$ & $10.33 \%$ & $10.33 \%$ \\
\hline E & $3,999.27$ & $4,250.92$ & $4,663.51$ & $4,808.13$ & $4,904.29$ & $5,002.37$ \\
\hline WACC & $8.995 \%$ & $9.035 \%$ & $9.096 \%$ & $9.112 \%$ & $9.112 \%$ & $9.112 \%$ \\
\hline WACC $_{\mathrm{BT}}$ & $9.759 \%$ & $9.765 \%$ & $9.777 \%$ & $9.778 \%$ & $9.778 \%$ & $9.778 \%$ \\
\hline$E+D$ & $5,499.27$ & $5,750.92$ & $6,163.51$ & $6,308.12$ & $6,434.29$ & $6,562.97$ \\
\hline EVA & & 93.10 & 258.59 & 265.89 & 275.82 & 281.34 \\
\hline EP & & 142.91 & 308.94 & 313.48 & 323.16 & 329.62 \\
\hline$E C F \backslash \backslash K u$ & & 148.28 & 12.50 & 321.74 & 384.65 & 392.34 \\
\hline FCFIIKu & & 298.28 & 162.50 & 471.74 & 504.65 & 514.74 \\
\hline$E C F \backslash \backslash R_{F}$ & & -11.69 & -157.54 & 135.20 & 192.33 & 196.17 \\
\hline $\mathrm{FCF} \backslash \backslash \mathrm{R}_{\mathrm{F}}$ & & 78.31 & -67.54 & 225.20 & 252.33 & 257.37 \\
\hline
\end{tabular}




\section{Table 8}

Valuation of Toro Inc. According to Miles and Ezzell

\begin{tabular}{|c|c|c|c|c|c|c|}
\hline & 0 & 1 & 2 & 3 & 4 & 5 \\
\hline VTS = PV[Ku; T D Kd] $(1+K u) /(1+K d)$ & 508.13 & 516.16 & 525.00 & 534.72 & 545.42 & 556.33 \\
\hline$\beta_{\llcorner}$ & 1.190077 & 1.178530 & 1.162292 & 1.157351 & 1.157351 & 1.157351 \\
\hline $\mathrm{Ke}$ & $10.76 \%$ & $10.71 \%$ & $10.65 \%$ & $10.63 \%$ & $10.63 \%$ & $10.63 \%$ \\
\hline E & $3,843.5$ & $4,092.1$ & $4,501.5$ & $4,642.8$ & $4,735.7$ & $4,830.4$ \\
\hline WACC & $9.199 \%$ & $9.235 \%$ & $9.287 \%$ & $9.304 \%$ & $9.304 \%$ & $9.304 \%$ \\
\hline WACC $_{\mathrm{BT}}$ & $9.985 \%$ & $9.986 \%$ & $9.987 \%$ & $9.987 \%$ & $9.987 \%$ & $9.987 \%$ \\
\hline$E+D$ & $5,343.48$ & $5,592.05$ & $6,001.48$ & $6,142.85$ & $6,265.70$ & $6,391.02$ \\
\hline EVA & & 89.01 & 254.53 & 261.36 & 271.17 & 276.60 \\
\hline EP & & 141.20 & 307.22 & 310.88 & 320.40 & 326.80 \\
\hline ECF $\backslash \backslash K u$ & & 135.78 & -0.22 & 308.78 & 371.43 & 378.86 \\
\hline FCFI\Ku & & 285.78 & 149.78 & 458.78 & 491.43 & 501.26 \\
\hline$E C F \backslash \backslash R_{F}$ & & -17.96 & -163.90 & 128.72 & 185.71 & 189.43 \\
\hline$F C F \backslash \backslash R_{F}$ & & 72.04 & -73.90 & 218.72 & 245.71 & 250.63 \\
\hline
\end{tabular}

\section{Table 9}

Valuation of Toro Inc. According to Miller

\begin{tabular}{|lrrrr|rr|}
\cline { 2 - 7 } \multicolumn{1}{c}{} & $\mathbf{0}$ & $\mathbf{1}$ & $\mathbf{2}$ & $\mathbf{3}$ & $\mathbf{4}$ & $\mathbf{5}$ \\
\hline $\mathrm{VTS}=0$ & 0 & 0 & 0 & 0 & 0 & 0 \\
\hline$\beta_{\mathrm{L}}$ & 1.539673 & 1.503371 & 1.452662 & 1.438156 & 1.438156 & 1.438156 \\
$\mathrm{Ke}$ & $12.16 \%$ & $12.01 \%$ & $11.81 \%$ & $11.75 \%$ & $11.75 \%$ & $11.75 \%$ \\
$\mathbf{E}=\mathrm{Vu}$ & $\mathbf{3 , 3 3 5 . 3 5}$ & $\mathbf{3 , 5 7 5 . 8 9}$ & $\mathbf{3 , 9 7 6 . 4 8}$ & $\mathbf{4 , 1 0 8 . 1 3}$ & $\mathbf{4 , 1 9 0 . 2 9}$ & $\mathbf{4 , 2 7 4 . 0 9}$ \\
\hline WACC=Ku & $10.000 \%$ & $10.000 \%$ & $10.000 \%$ & $10.000 \%$ & $10.000 \%$ & $10.000 \%$ \\
WACC & $10.869 \%$ & $10.827 \%$ & $10.767 \%$ & $10.749 \%$ & $10.749 \%$ & $10.749 \%$ \\
E+D & $4,835.35$ & $5,075.89$ & $5,476.48$ & $5,608.13$ & $5,720.29$ & $5,834.69$ \\
\hline EVA & & 73.00 & 239.00 & 244.50 & 254.25 & 259.34 \\
EP & & 134.21 & 300.33 & 300.84 & 309.95 & 316.15 \\
\hline ECF $\backslash \backslash \mathrm{Ku}$ & & 93.00 & -43.00 & 266.00 & 328.65 & 335.22 \\
FCF $\backslash \backslash \mathrm{Ku}$ & & 243.00 & 107.00 & 416.00 & 448.65 & 457.62 \\
\hline ECF $\backslash \backslash \mathrm{R}_{\mathrm{F}}$ & & -40.41 & -186.04 & 106.94 & 164.33 & 167.61 \\
FCF $\backslash \backslash \mathrm{R}_{\mathrm{F}}$ & & 49.59 & -96.04 & 196.94 & 224.33 & 228.81 \\
\hline
\end{tabular}




\section{Table 10}

Valuation of Toro Inc. According to the With-cost-of-leverage Theory

\begin{tabular}{|c|c|c|c|c|c|c|}
\hline & 0 & 1 & 2 & 3 & 4 & 5 \\
\hline$V T S=P V\left[K u ; D\left(K u T+R_{F}-K d\right)\right]$ & 267.26 & 271.49 & 276.14 & 281.25 & 286.88 & 292.61 \\
\hline$\beta_{\llcorner}$ & 1.343501 & 1.321648 & 1.290998 & 1.281931 & 1.281931 & 1.281931 \\
\hline $\mathrm{Ke}$ & $11.37 \%$ & $11.29 \%$ & $11.16 \%$ & $11.13 \%$ & $11.13 \%$ & $11.13 \%$ \\
\hline E & $3,602.61$ & $3,847.38$ & $4,252.61$ & $4,389.38$ & $4,477.16$ & $4,566.71$ \\
\hline WACC & $9.559 \%$ & $9.579 \%$ & $9.609 \%$ & $9.618 \%$ & $9.618 \%$ & $9.618 \%$ \\
\hline WACC $_{\mathrm{BT}}$ & $10.382 \%$ & $10.365 \%$ & $10.339 \%$ & $10.331 \%$ & $10.331 \%$ & $10.331 \%$ \\
\hline$E+D$ & $5,102.61$ & $5,347.38$ & $5,752.61$ & $5,889.38$ & $6,007.16$ & $6,127.31$ \\
\hline EVA & & 81.82 & 247.54 & 253.75 & 263.53 & 268.80 \\
\hline EP & & 138.13 & 304.18 & 306.43 & 315.76 & 322.08 \\
\hline ECFIIKu & & 115.50 & -20.50 & 288.50 & 351.15 & 358.17 \\
\hline $\mathrm{FCF} \backslash \backslash \mathrm{Ku}$ & & 265.50 & 129.50 & 438.50 & 471.15 & 480.57 \\
\hline$E C F \backslash \backslash R_{F}$ & & -28.60 & -174.40 & 118.40 & 175.58 & 179.09 \\
\hline $\mathrm{FCF} \backslash \backslash \mathrm{R}_{\mathrm{F}}$ & & 61.40 & -84.40 & 208.40 & 235.58 & 240.29 \\
\hline
\end{tabular}

\section{Table 11}

Valuation of Toro Inc. According to Modigliani and Miller

\begin{tabular}{|c|c|c|c|c|c|c|}
\hline & 0 & 1 & 2 & 3 & 4 & 5 \\
\hline $\mathrm{VTS}=\mathrm{PV}\left[\mathrm{R}_{\mathrm{F}} ; \mathrm{D} \mathrm{R}_{\mathrm{F}} \mathrm{T}\right]$ & 745.40 & 758.62 & 772.64 & 787.50 & 803.25 & 819.31 \\
\hline$\beta_{L}$ & 1.065454 & 1.058571 & 1.050506 & 1.045959 & 1.045959 & 1.045959 \\
\hline $\mathrm{Ke}$ & $10.26 \%$ & $10.23 \%$ & $10.20 \%$ & $10.18 \%$ & $10.18 \%$ & $10.18 \%$ \\
\hline $\mathbf{E}$ & $4,080.75$ & $4,334.51$ & $4,749.12$ & $4,895.62$ & $4,993.54$ & $5,093.41$ \\
\hline WACC & $8.901 \%$ & $8.940 \%$ & $9.001 \%$ & $9.015 \%$ & $9.015 \%$ & $9.015 \%$ \\
\hline WACC $_{\mathrm{BT}}$ & $9.654 \%$ & $9.660 \%$ & $9.673 \%$ & $9.672 \%$ & $9.672 \%$ & $9.672 \%$ \\
\hline$E+D$ & $5,580.75$ & $5,834.51$ & $6,249.12$ & $6,395.62$ & $6,523.54$ & $6,654.01$ \\
\hline EVA & & 94.97 & 260.52 & 268.12 & 278.19 & 283.75 \\
\hline EP & & 143.69 & 309.76 & 314.75 & 324.54 & 331.03 \\
\hline$E C F \backslash \backslash K u$ & & 154.32 & 18.84 & 328.41 & 391.65 & 399.48 \\
\hline $\mathrm{FCF} \backslash \backslash \mathrm{Ku}$ & & 304.32 & 168.84 & 478.41 & 511.65 & 521.88 \\
\hline$E C F \backslash \backslash R_{F}$ & & -8.91 & -154.54 & 138.44 & 195.83 & 199.74 \\
\hline$F C F \backslash \backslash R_{F}$ & & 81.09 & -64.54 & 228.44 & 255.83 & 260.94 \\
\hline
\end{tabular}

Table 12 is a compendium of the valuations of Toro Inc. performed according to the nine theories. It can be seen that Modigliani and Miller gives the highest equity value $(4,080.75)$ and Miller the lowest $(3,335.35)$. Note that Modigliani and Miller and Myers yield a higher equity value than the Fernández (2004) theory. This result is inconsistent, as discussed in Fernández (2002). 


\section{Table 12}

Valuation of Toro Inc. According to the Nine Theories

\begin{tabular}{|l|r|r|r|r|r|}
\cline { 5 - 6 } \multicolumn{1}{c|}{} & Equity & Value of tax & Leverage & \multicolumn{2}{|c|}{ Ke } \\
\cline { 5 - 6 } \multicolumn{1}{c|}{ Value in $t=0)$} & value (E) & shield (VTS) & cost & $\mathbf{t}=\mathbf{0}$ & $\mathbf{t}=\mathbf{4}$ \\
\hline Fernández (2004) & $3,958.96$ & 623.61 & 0.00 & $10.49 \%$ & $10.41 \%$ \\
\hline Damodaran & $3,727.34$ & 391.98 & 231.63 & $11.05 \%$ & $10.86 \%$ \\
\hline Practitioners' & $3,477.89$ & 142.54 & 481.07 & $11.73 \%$ & $11.41 \%$ \\
\hline Harris and Pringle & $3,834.24$ & 498.89 & 124.72 & $10.78 \%$ & $10.65 \%$ \\
\hline Myers & $3,999.27$ & 663.92 & -40.31 & $10.42 \%$ & $10.33 \%$ \\
\hline Miles and Ezzell & $3,843.48$ & 508.13 & 115.48 & $10.76 \%$ & $10.63 \%$ \\
\hline Miller & $3,335.35$ & 0.00 & 623.61 & $12.16 \%$ & $11.75 \%$ \\
\hline With-cost-of-leverage & $3,602.61$ & 267.26 & 356.35 & $11.37 \%$ & $11.13 \%$ \\
\hline Modigliani and Miller & $4,080.75$ & 745.40 & -121.79 & $10.26 \%$ & $10.18 \%$ \\
\hline
\end{tabular}

\section{Table 13}

Valuation of Toro Inc. According to the Nine Theories if Growth After Year 3 is 5.6\% Instead of 2\%

\begin{tabular}{|l|r|r|r|r|r|}
\cline { 5 - 6 } \multicolumn{1}{c|}{} & Equity & Value of tax & Leverage & \multicolumn{2}{|c|}{ Ke } \\
\cline { 5 - 6 } \multicolumn{1}{c|}{ Value in $t=0)$} & value (E) & shield (VTS) & cost & t = $\mathbf{0}$ & $\mathbf{t}=\mathbf{4}$ \\
\hline Fernández (2004) & $6,615.67$ & $1,027.01$ & 0.00 & $10.29 \%$ & $10.23 \%$ \\
\hline Damodaran & $6,234.21$ & 645.55 & 381.46 & $10.63 \%$ & $10.50 \%$ \\
\hline Practitioners' & $5,823.40$ & 234.75 & 792.27 & $11.03 \%$ & $10.81 \%$ \\
\hline Harris and Pringle & $6,410.27$ & 821.61 & 205.40 & $10.47 \%$ & $10.37 \%$ \\
\hline Myers & $7,086.10$ & $1,497.44$ & -470.43 & $\mathbf{1 0 . 0 0 \%}$ & $\mathbf{9 . 9 4 \%}$ \\
\hline Miles and Ezzell & $6,425.48$ & 836.83 & 190.19 & $10.45 \%$ & $10.36 \%$ \\
\hline Miller & $5,588.66$ & 0.00 & $1,027.01$ & $11.29 \%$ & $11.01 \%$ \\
\hline With-cost-of-leverage & $6,028.81$ & 440.15 & 586.87 & $10.82 \%$ & $10.65 \%$ \\
\hline Modigliani and Miller & $12,284.86$ & $6,696.20$ & $-5,669.19$ & $\mathbf{8 . 1 5 \%}$ & $\mathbf{8 . 1 7 \%}$ \\
\hline
\end{tabular}

Table 13 is the valuation of Toro Inc. if the growth after year 3 were 5.6\% instead of 2\%. Modigliani and Miller and Myers provide a required return on equity (Ke) lower than the required return on unlevered equity $(\mathrm{Ku}=10 \%)$, which is an inconsistent result because it does not make any economic sense.

\section{How Is the Company Valued when It Reports Losses in One or More Years?}

In such cases, we must calculate the tax rate that the company will pay, and this is the rate that must be used to perform all the calculations. It is as if the tax rate were the rate obtained after subtracting the taxes that the company must pay. 
Example. The company Campa S.A. reports a loss in year 1 . The tax rate is $35 \%$. In year 1 , it will not pay any taxes as it has suffered losses amounting to 220 million. In year 2, it will pay corporate taxes amounting to 35\% of that year's profit less the previous year's losses (350 220). The resulting tax is 45.5 , that is, $13 \%$ of the EBT for year 2. Consequently, the effective tax rate is zero in year 1, 13\% in year 2, and 35\% in the other years.

\section{Conclusion}

The paper shows that the ten most commonly used methods for valuing companies by discounted cash flows always give the same value. This result is logical, since all the methods analyze the same reality under the same hypotheses; they differ only in the cash flows taken as the starting point for the valuation. The ten methods analyzed are:

1) Free cash flow discounted at the WACC;

2) Equity cash flows discounted at the required return on equity;

3) Capital cash flows discounted at the WACC before tax;

4) APV (adjusted present value);

5) The business's risk-adjusted free cash flows discounted at the required return on assets;

6) The business's risk-adjusted equity cash flows discounted at the required return on assets;

7) Economic profit discounted at the required return on equity;

8) EVA discounted at the WACC;

9) The risk-free rate-adjusted free cash flows discounted at the risk-free rate; and

10) The risk-free rate-adjusted equity cash flows discounted at the required return on assets.

The paper also analyses nine different theories on the calculation of the VTS, which implies nine different theories on the relationship between the levered and the unlevered beta, and nine different theories on the relationship between the required return on equity and the required return on assets. The nine theories analyzed are:

1) Fernández (2004),

2) Modigliani and Miller (1963),

3) Myers (1974),

4) Miller (1977),

5) Miles and Ezzell (1980),

6) Harris and Pringle (1985),

7) Damodaran (1994),

8) With-cost-of-leverage, and

9) Practitioners' method. 
The differences between the various theories on the valuation of the firm arise from the calculation of the value of the tax shields (VTS). Using a simple example, we show that Modigliani and Miller (1963) and Myers (1974) provide inconsistent results.

The paper contains the most important valuation equations according to these theories (Appendix 2) and also shows how the valuation equations change if the debt's market value is not equal to its book value (Appendix 3). 


\section{Appendix 1}

A Brief Overview of the Most Significant Papers on the Discounted Cash Flow Valuation of Firms

There is a considerable body of literature on the discounted cash flow valuation of firms. We will now discuss the most salient papers, concentrating particularly on those that propose different expressions for the present value of the tax savings due to the payment of interest or value of tax shields (VTS). The main problem with most papers is that they consider the value of tax shields (VTS) as the present value of the tax savings due to the payment of interest. Fernández (2004) argues that the value of tax shields (VTS) is the difference between two present values: the present value of taxes paid by the unlevered firm and the present value of taxes paid by the levered firm.

Modigliani and Miller (1958) studied the effect of leverage on the firm's value. Their proposition 1 (1958, equation 3) states that, in the absence of taxes, the firm's value is independent of its debt, i.e.,

$$
\text { [23] } \mathrm{E}+\mathrm{D}=\mathrm{Vu} \text {, if } \mathrm{T}=0
$$

$\mathrm{E}$ is the equity value, $\mathrm{D}$ is the debt value, $\mathrm{Vu}$ is the value of the unlevered company, and $\mathrm{T}$ is the tax rate.

In the presence of taxes and for the case of a perpetuity, they calculate the value of tax shields (VTS) by discounting the present value of the tax savings due to interest payments on a riskfree debt $\left(T D R_{F}\right)$ at the risk-free rate $\left(R_{F}\right)$. Their first proposition, with taxes, is transformed into Modigliani and Miller (1963, page 436) equation 3:

$$
[24] \mathrm{E}+\mathrm{D}=\mathrm{Vu}+\mathrm{PV}\left[\mathrm{R}_{\mathrm{F}} ; \mathrm{DT} \mathrm{R}_{\mathrm{F}}\right]=\mathrm{Vu}+\mathrm{D} \mathrm{T}
$$

DT is the value of tax shields (VTS) for perpetuity. This result is only correct for perpetuities. As Fernández (2004) demonstrates, discounting the tax savings due to interest payments on a risk-free debt at the risk-free rate provides inconsistent results for growing companies. We have seen this in Table 13.

Myers (1974) introduced the APV (adjusted present value). According to Myers, the value of the levered firm is equal to the value of the firm with no debt $(\mathrm{Vu})$ plus the present value of the tax saving due to the payment of interest (VTS). Myers proposes calculating the VTS by discounting the tax savings (D T Kd) at the cost of debt (Kd). The argument is that the risk of the tax saving arising from the use of debt is the same as the risk of the debt. Therefore, according to Myers (1974):

$$
\text { [25] VTS = PV [Kd; D T Kd] }
$$

Luehrman (1997) recommends valuing companies using the adjusted present value and calculates the VTS in the same way as Myers. This theory yields inconsistent results for growing companies, as shown in Fernández (2004). Fernández (2006) shows that this theory yields consistent results only if the expected debt levels are fixed.

Miller (1977) assumes no advantages of debt financing: "I argue that even in a world in which interest payments are fully deductible in computing corporate income taxes, the value of the firm, in equilibrium, will still be independent of its capital structure." According to Miller (1977), the value of the firm is independent of its capital structure, that is,

$$
\text { [26] } \mathrm{VTS}=0
$$




\section{Appendix 1 (continued)}

According to Miles and Ezzell (1980), a firm that wishes to keep a constant D/E ratio must be valued in a different manner from a firm that has a preset level of debt. For a firm with a fixed debt target $[D /(D+E)]$, they claim that the correct rate for discounting the tax saving due to debt $\left(\mathrm{Kd} \mathrm{T} \mathrm{D}_{\mathrm{t}-1}\right)$ is $\mathrm{Kd}$ for the tax saving during the first year, and $\mathrm{Ku}$ for the tax saving during the following years. The expression of Ke is their equation 22:

$$
[27] \mathrm{Ke}=\mathrm{Ku}+\mathrm{D}(\mathrm{Ku}-\mathrm{Kd})[1+\mathrm{Kd}(1-\mathrm{T})] /[(1+\mathrm{Kd}) \mathrm{E}]
$$

Arzac and Glosten (2005) and Cooper and Nyborg (2006) show that equation [27] implies that the value of tax shields is:

$$
\text { [28] VTS = PV[Ku; T D Kd] }(1+\mathrm{Ku}) /(1+\mathrm{Kd})
$$

Lewellen and Emery (1986) also claim that the most logically consistent method is Miles and Ezzell.

Harris and Pringle (1985) propose that the present value of the tax saving due to the payment of interest (VTS) should be calculated by discounting the tax saving due to the debt (Kd T D) at the rate $\mathrm{Ku}$. Their argument is that the interest tax shields have the same systematic risk as the firm's underlying cash flows and, therefore, should be discounted at the required return on assets $(\mathrm{Ku})$.

Therefore, according to Harris and Pringle (1985):

$$
\text { [29] VTS = PV }[\mathrm{Ku} ; \mathrm{D} \mathrm{Kd} \mathrm{T}]
$$

Harris and Pringle (1985, page 242) say "the MM position is considered too extreme by some because it implies that interest tax shields are no more risky than the interest payments themselves. The Miller position is too extreme for some because it implies that debt cannot benefit the firm at all. Thus, if the truth about the value of tax shields lies somewhere between the MM and Miller positions, a supporter of either Harris and Pringle or Miles and Ezzell can take comfort in the fact that both produce a result for unlevered returns between those of MM and Miller. A virtue of Harris and Pringle compared to Miles and Ezzell is its simplicity and straightforward intuitive explanation." Ruback $(1995,2002)$ reaches equations that are identical to those of Harris-Pringle (1985). Kaplan and Ruback (1995) also calculate the VTS "discounting interest tax shields at the discount rate for an all-equity firm". Tham and VélezPareja (2001), following an arbitrage argument, also claim that the appropriate discount rate for the tax shield is $\mathrm{Ku}$, the required return on unlevered equity. Fernández (2002) shows that Harris and Pringle (1985) provide inconsistent results.

Damodaran (1994, page 31) argues that if all the business risk is borne by the equity, then the equation relating the levered beta $\left(\beta_{\mathrm{L}}\right)$ to the asset beta $(\mathrm{Bu})$ is:

$$
\text { [30] } \beta_{L}=\beta u+(D / E) B u(1-T)
$$

It is important to note that equation [30] is exactly the same as equation [22] assuming that $\mathrm{Bd}$ $=0$. One interpretation of this assumption is that all of the firm's risk is borne by the stockholders (i.e., the beta of the debt is zero). However, we think that it is difficult to justify that the debt has no risk (unless the cost of debt is the risk-free rate) and that the return on the 


\section{Appendix 1 (continued)}

debt is uncorrelated with the return on assets of the firm. We rather interpret equation [30] as an attempt to introduce some leverage costs into the valuation; for a given risk of the assets ( $\mathrm{Bu}$ ), by using equation [30] we obtain a higher $\beta_{\mathrm{L}}$ (and consequently a higher Ke and a lower equity value) than with equation [22]. Equation [30] appears in many finance books and is used by some consultants and investment banks.

Although Damodaran does not mention what the value of tax shields should be, his equation [30] relating the levered beta to the asset beta implies that the value of tax shields is:

[31] VTS = PV[Ku; D T Ku - D $\left.\left(\mathrm{Kd}-\mathrm{R}_{\mathrm{F}}\right)(1-\mathrm{T})\right]$

Another way of calculating the levered beta with respect to the asset beta is the following:

[32] $\beta_{L}=\beta u(1+D / E)$

We will call this method the Practitioners' method, because consultants and investment banks often use it (one of the many places where it appears is Ruback (1995, page 5)). It is obvious that according to this equation, given the same value for $\mathrm{Bu}$, a higher $\beta_{\mathrm{L}}$ (and a higher Ke and a lower equity value) is obtained than according to [22] and [30].

Notice that equation [32] is equal to equation [30] eliminating the (1-T) term. We interpret equation [32] as an attempt to introduce still higher leverage costs into the valuation; for a given risk of the assets ( $\mathrm{Bu}$ ), by using equation [32] we obtain a higher $\beta_{\mathrm{L}}$ (and consequently a higher Ke and a lower equity value) than with equation [30].

Equation [32] relating the levered beta with the asset beta implies that the value of tax shields is:

[33] VTS = PV[Ku; D T Kd - D $\left.\left(K d-R_{F}\right)\right]$

By comparing [33] to [31] it can be seen that [33] provides a VTS that is PV[Ku; D T $\left.\left(\mathrm{Ku}-\mathrm{R}_{\mathrm{F}}\right)\right]$ lower than [31]. We interpret this difference as additional leverage cost (on top of the leverage cost of Damodaran) introduced in the valuation.

Inselbag and Kaufold (1997) argue that if the firm targets the dollar values of debt outstanding, the VTS is given by the Myers (1974) equation. However, if the firm targets a constant debt/value ratio, the VTS is given by the Miles and Ezzell (1980) equation.

Copeland, Koller and Murrin (2000) deal with the adjusted present value in their Appendix A. They only mention perpetuities and only propose two ways of calculating the VTS: Harris and Pringle (1985) and Myers (1974). They conclude "we leave it to the reader's judgment to decide which approach best fits his or her situation." They also claim that "the finance literature does not provide a clear answer about which discount rate for the tax benefit of interest is theoretically correct." It is quite interesting to note that Copeland et al. (2000, page 483) only suggest Inselbag and Kaufold (1997) as additional reading on adjusted present value.

We will consider two additional theories to calculate the value of tax shields. We label these two theories Fernández (2004) (or No-costs-of-leverage), and With-costs-of-leverage. 


\section{Appendix 1 (continued)}

According to Fernández (2004), the VTS is the present value of DTKu (not the interest tax shield) discounted at the unlevered cost of equity (Ku).

\section{[34] PV[Ku; D T Ku]}

Equation [34] is the result of considering that the value of tax shields (VTS) is the difference between two present values: the present value of taxes paid by the unlevered firm and the present value of taxes paid by the levered firm. It can be seen in Fernández (2004).

Comparing [31] to [34], it can be seen that [31] provides a VTS that is PV[Ku; D (Kd- $\left.\mathrm{R}_{\mathrm{F}}\right)(1-\mathrm{T})$ ] lower than [34]. We interpret this difference as a leverage cost introduced into the valuation by Damodaran.

Comparing [33] to [34], it can be seen that [33] provides a VTS that is PV[Ku; D T (Ku-Kd) + $\mathrm{D}\left(\mathrm{Kd}-\mathrm{R}_{\mathrm{F}}\right)$ ] lower than [34]. We interpret this difference as a leverage cost introduced into the valuation by the Practitioners' method.

With-costs-of-leverage. This theory provides another way of quantifying the VTS:

$$
\text { [35] VTS = PV[Ku; D Ku T - D } \left.\left(\mathrm{Kd}-\mathrm{R}_{\mathrm{F}}\right)\right]
$$

One way of interpreting equation [35] is that the leverage costs (with respect to [34]) are proportional to the amount of debt and to the difference between the required return on debt and the risk-free rate. This formula can be completed with another parameter $\varphi$ that takes into account that the cost of leverage is not strictly proportional to debt. $\varphi$ should be lower for small leverage and higher for high leverage. Introducing this parameter, the value of tax shields is $\mathrm{VTS}=\mathrm{PV}\left[\mathrm{Ku} ; \mathrm{D} \mathrm{T} \mathrm{Ku}-\varphi \mathrm{D}\left(\mathrm{Kd}-\mathrm{R}_{\mathrm{F}}\right)\right]$

By comparing [35] to [34], it can be seen that [40] provides a VTS that is $\mathrm{PV}\left[\mathrm{Ku}\right.$; $\left.\mathrm{D}\left(\mathrm{Kd}-\mathrm{R}_{\mathrm{F}}\right)\right]$ lower than [34]. We interpret this difference as a leverage cost introduced into the valuation.

The following table provides a synthesis of the nine theories about the value of tax shields applied to level perpetuities.

\section{Perpetuities. Value of Tax Shields (VTS) According to the Nine Theories}

\begin{tabular}{|c|l|c|l|}
\hline & Theory & Equation & VTS \\
\hline 1 & Fernández (2004) & {$[34]$} & $\mathrm{DT}$ \\
\hline 2 & Damodaran & {$[31]$} & $\mathrm{DT}-\left[\mathrm{D}\left(\mathrm{Kd}-\mathrm{R}_{\mathrm{F}}\right)(1-\mathrm{T})\right] / \mathrm{Ku}$ \\
\hline 3 & Practitioners' & {$[33]$} & $\mathrm{D}\left[\mathrm{R}_{\mathrm{F}}-\mathrm{Kd}(1-\mathrm{T})\right] / \mathrm{Ku}$ \\
\hline 4 & Harris-Pringle & {$[29]$} & $\mathrm{T} \mathrm{D} \mathrm{Kd} / \mathrm{Ku}$ \\
\hline 5 & Myers & {$[25]$} & $\mathrm{DT}$ \\
\hline 6 & Miles-Ezzell & {$[28]$} & $\mathrm{TDKd}(1+\mathrm{Ku}) /[(1+\mathrm{Kd}) \mathrm{Ku}]$ \\
\hline 7 & Miller (1977) & {$[26]$} & 0 \\
\hline 8 & With-costs-of-leverage & {$[35]$} & $\mathrm{D}\left(\mathrm{KuT}+\mathrm{R}_{\mathrm{F}}-\mathrm{Kd}\right) / \mathrm{Ku}$ \\
\hline 9 & Modigliani-Miller & {$[24]$} & $\mathrm{DT}$ \\
\hline
\end{tabular}




\section{Appendix 1 (continued)}

Fernández (2006) shows that only three of them may be correct:

- When the debt level is fixed, Modigliani-Miller or Myers apply, and the tax shields should be discounted at the required return on debt.

- If the leverage ratio is fixed at market value, then Miles-Ezzell applies.

- If the leverage ratio is fixed at book value, and the appropriate discount rate for the expected increases of debt is $\mathrm{Ku}$, then Fernández (2004) applies. 


\section{Appendix 2}

Valuation Equations According to the Main Theories

Market Value of the Debt $=$ Nominal Value

\begin{tabular}{|c|c|c|}
\hline & Fernández (2004) & Damodaran (1994) \\
\hline $\mathrm{Ke}$ & $\mathrm{Ke}=\mathrm{Ku}+\frac{\mathrm{D}(1-\mathrm{T})}{\mathrm{E}}(\mathrm{Ku}-\mathrm{Kd})$ & $\mathrm{Ke}=\mathrm{Ku}+\frac{\mathrm{D}(1-\mathrm{T})}{\mathrm{E}}\left(\mathrm{Ku}-\mathrm{R}_{\mathrm{F}}\right)$ \\
\hline$B_{\mathrm{L}}$ & $\beta_{L}=\beta u+\frac{D(1-T)}{E}(\beta u-\beta d)$ & $\beta_{L}=\beta u+\frac{D(1-T)}{E} \beta u$ \\
\hline WACC & $\mathrm{Ku}\left(1-\frac{\mathrm{DT}}{\mathrm{E}+\mathrm{D}}\right)$ & $\mathrm{Ku}\left(1-\frac{\mathrm{DT}}{\mathrm{E}+\mathrm{D}}\right)+\mathrm{D} \frac{\left(\mathrm{Kd}-\mathrm{R}_{\mathrm{F}}\right)(1-\mathrm{T})}{\mathrm{E}+\mathrm{D}}$ \\
\hline WACC $_{\mathrm{BT}}$ & $\mathrm{Ku}-\frac{\mathrm{DT}(\mathrm{Ku}-\mathrm{Kd})}{\mathrm{E}+\mathrm{D}}$ & $\mathrm{Ku}-\mathrm{D} \frac{\mathrm{T}\left(\mathrm{Ku}-\mathrm{R}_{\mathrm{F}}\right)-\left(\mathrm{Kd}-\mathrm{R}_{\mathrm{F}}\right)}{\mathrm{E}+\mathrm{D}}$ \\
\hline VTS & $\mathrm{PV}[\mathrm{Ku} ; \mathrm{DTKu}]$ & $\mathrm{PV}\left[\mathrm{Ku} ; \mathrm{DTKu}-\mathrm{D}\left(\mathrm{Kd}-\mathrm{R}_{\mathrm{F}}\right)(1-\mathrm{T})\right]$ \\
\hline $\mathrm{ECF}_{\mathrm{t}} \| \mathrm{Ku}$ & $E C F_{t}-D_{t-1}\left(K u_{t}-K d_{t}\right)(1-T)$ & $E C F_{t}-D_{t-1}\left(K u-R_{F}\right)(1-T)$ \\
\hline $\mathrm{FCF}_{\mathrm{t}} \| \mathrm{Ku}$ & $\mathrm{FCF}_{\mathrm{t}}+\mathrm{D}_{\mathrm{t}-1} \mathrm{Ku}_{\mathrm{t}} \mathrm{T}$ & $\mathrm{FCF}_{\mathrm{t}}+\mathrm{D}_{\mathrm{t}-1} \mathrm{Ku} \mathrm{T}-\mathrm{D}_{\mathrm{t}-1}\left(\mathrm{Kd}-\mathrm{R}_{\mathrm{F}}\right)(1-\mathrm{T})$ \\
\hline $\mathrm{ECF}_{\mathrm{t}} \| \mathrm{R}_{\mathrm{F}}$ & 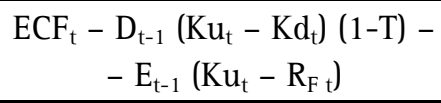 & $\begin{array}{c}E^{E C F_{t}}-D_{t-1}\left(K u-R_{F}\right)(1-T)- \\
-E_{t-1}\left(K u_{t}-R_{F}\right)\end{array}$ \\
\hline $\mathrm{FCF}_{\mathrm{t}} \| \mathrm{R}_{\mathrm{F}}$ & $\begin{array}{c}\mathrm{FCF}_{\mathrm{t}}+\mathrm{D}_{\mathrm{t}-1} \mathrm{Ku}_{\mathrm{t}} \mathrm{T}- \\
-\left(\mathrm{E}_{\mathrm{t}-1}+\mathrm{D}_{\mathrm{t}-1}\right)\left(\mathrm{Ku}_{\mathrm{t}}-\mathrm{R}_{\mathrm{F}}\right) \\
\end{array}$ & $\begin{array}{c}\mathrm{FCF}_{\mathrm{t}}+\mathrm{D}_{\mathrm{t}-1} \mathrm{Ku} \mathrm{T}-\mathrm{D}_{\mathrm{t}-1}\left(\mathrm{Kd}-\mathrm{R}_{\mathrm{F}}\right)(1-\mathrm{T})-\left(\mathrm{E}_{\mathrm{t}-1}\right. \\
\left.+\mathrm{D}_{\mathrm{t}-1}\right)\left(\mathrm{Ku}_{\mathrm{t}}-\mathrm{R}_{\mathrm{F}}\right)\end{array}$ \\
\hline
\end{tabular}

\begin{tabular}{|c|c|c|c|}
\hline & $\begin{array}{l}\text { Harris-Pringle (1985) } \\
\text { Ruback (1995) }\end{array}$ & Myers (1974) & Miles-Ezzell (1980) \\
\hline Ke & $K e=K u+\frac{D}{E}(K u-K d)$ & $\mathrm{Ke}=\mathrm{Ku}+\frac{\mathrm{Vu}-\mathrm{E}}{\mathrm{E}}(\mathrm{Ku}-\mathrm{Kd})$ & $\mathrm{Ke}=\mathrm{Ku}+\frac{\mathrm{D}}{\mathrm{E}}(\mathrm{Ku}-\mathrm{Kd})\left[1-\frac{\mathrm{TKd}}{1+\mathrm{Kd}}\right]$ \\
\hline$\beta_{\mathrm{L}}$ & $\beta_{L}=\beta u+\frac{D}{E}(\beta u-\beta d)$ & $\beta_{\mathrm{L}}=\beta \mathrm{u}+\frac{\mathrm{Vu}-\mathrm{E}}{\mathrm{E}}(\beta \mathrm{u}-\beta \mathrm{d})$ & $\beta_{\mathrm{L}}=\beta \mathrm{u}+\frac{\mathrm{D}}{\mathrm{E}}(\beta \mathrm{u}-\beta \mathrm{d})\left[1-\frac{\mathrm{TKd}}{1+\mathrm{Kd}}\right]$ \\
\hline WACC & $\mathrm{Ku}-\frac{\mathrm{DKdT}}{\mathrm{E}+\mathrm{D}}$ & $\mathrm{Ku}-\frac{\mathrm{VTS}(\mathrm{Ku}-\mathrm{Kd})+\mathrm{DKdT}}{\mathrm{E}+\mathrm{D}}$ & $\mathrm{Ku}-\frac{\mathrm{DKdT}}{\mathrm{E}+\mathrm{D}} \frac{1+\mathrm{Ku}}{1+\mathrm{Kd}_{0}}$ \\
\hline WACC $_{\text {BT }}$ & $\mathrm{Ku}$ & $\mathrm{Ku}-\frac{\mathrm{VTS}(\mathrm{Ku}-\mathrm{Kd})}{\mathrm{E}+\mathrm{D}}$ & $\mathrm{Ku}-\frac{\mathrm{DKdT}}{\mathrm{E}+\mathrm{D}} \frac{(\mathrm{Ku}-\mathrm{Kd})}{\left(1+\mathrm{Kd}_{0}\right)}$ \\
\hline VTS & $\mathrm{PV}[\mathrm{Ku} ; \mathrm{T} \mathrm{D} \mathrm{Kd}]$ & $\mathrm{PV}[\mathrm{Kd} ; \mathrm{T} \mathrm{D} \mathrm{Kd}]$ & $\mathrm{PV}[\mathrm{Ku} ; \mathrm{T}$ D Kd] $(1+\mathrm{Ku}) /(1+\mathrm{Kd})$ \\
\hline$\overline{E^{\prime} F_{t} \| K u}$ & $\mathrm{ECF}_{\mathrm{t}}-\mathrm{D}_{\mathrm{t}-1}\left(\mathrm{Ku}_{\mathrm{t}}-\mathrm{Kd}_{\mathrm{t}}\right)$ & $E C F_{t}-(V u-E)\left(K u_{t}-K d_{t}\right)$ & $\mathrm{ECF}-\mathrm{D}(\mathrm{Ku}-\mathrm{Kd}) \frac{1+\mathrm{Kd}(1-\mathrm{T})}{\left(1+\mathrm{Kd}_{0}\right)}$ \\
\hline $\mathrm{FCF}_{t} \| \mathrm{Ku}$ & $\mathrm{FCF}_{\mathrm{t}}+\mathrm{T} \mathrm{D}_{\mathrm{t}-1} \mathrm{Kd}_{\mathrm{t}}$ & $\mathrm{FCF}_{\mathrm{t}}+\mathrm{T} \mathrm{D} \mathrm{Kd}+\mathrm{VTS}(\mathrm{Ku}-\mathrm{Kd})$ & FCF +T D Kd $(1+K u) /(1+K d)$ \\
\hline$\overline{E^{\prime} F_{t} \| R_{F}}$ & $\begin{array}{c}\mathrm{ECF}_{\mathrm{t}}-\mathrm{D}_{\mathrm{t}-1}\left(\mathrm{Ku}_{\mathrm{t}}-\mathrm{Kd}_{\mathrm{t}}\right)- \\
-\mathrm{E}_{\mathrm{t}-1}\left(\mathrm{Ku}_{\mathrm{t}}-\mathrm{R}_{\mathrm{F}}\right)\end{array}$ & $\begin{array}{c}\mathrm{ECF}_{\mathrm{t}}-(\mathrm{Vu}-\mathrm{E})\left(\mathrm{Ku}_{\mathrm{t}}-\mathrm{Kd}_{\mathrm{t}}\right)- \\
-\mathrm{E}_{\mathrm{t}-1}\left(\mathrm{Ku}_{\mathrm{t}}-\mathrm{R}_{\mathrm{F}}\right)\end{array}$ & $\begin{array}{c}\mathrm{ECF}-\mathrm{D}(\mathrm{Ku}-\mathrm{Kd}) \frac{1+\mathrm{Kd}(1-\mathrm{T})}{\left(1+\mathrm{Kd}_{0}\right)}- \\
-\mathrm{E}_{\mathrm{t}-1}\left(\mathrm{Ku}_{\mathrm{t}}-\mathrm{R}_{\mathrm{F}}\right)\end{array}$ \\
\hline $\mathrm{FCF}_{\mathrm{t}} \| \mathrm{R}_{\mathrm{F}}$ & $\begin{array}{c}\mathrm{FCF}_{\mathrm{t}}+\mathrm{T} \mathrm{D}_{\mathrm{t}-1} \mathrm{Kd}_{\mathrm{t}}- \\
-\left(\mathrm{E}_{\mathrm{t}-1}+\mathrm{D}_{\mathrm{t}-1}\right)\left(\mathrm{Ku}_{\mathrm{t}}-\mathrm{R}_{\mathrm{Ft}}\right) \\
\end{array}$ & $\begin{array}{c}\mathrm{FCF}_{\mathrm{t}}+\mathrm{T} \mathrm{D} \mathrm{Kd}+\mathrm{VTS}(\mathrm{Ku}-\mathrm{Kd}) \\
-\left(\mathrm{E}_{\mathrm{t}-1}+\mathrm{D}_{\mathrm{t}-1}\right)\left(\mathrm{Ku}_{\mathrm{t}}-\mathrm{R}_{\mathrm{Ft}}\right) \\
\end{array}$ & $\begin{array}{c}\text { FCF }+ \text { T D Kd }(1+K u) /(1+K d)- \\
-\left(E_{t-1}+D_{t-1}\right)\left(K_{t}-R_{F t}\right)\end{array}$ \\
\hline
\end{tabular}




\section{Appendix 2 (continued)}

\begin{tabular}{|c|c|c|}
\hline & Miller & With-cost-of-leverage \\
\hline Ke & $\mathrm{Ke}=\mathrm{Ku}+\frac{\mathrm{D}}{\mathrm{E}}[\mathrm{Ku}-\mathrm{Kd}(1-\mathrm{T})]$ & $\mathrm{Ke}=\mathrm{Ku}+\frac{\mathrm{D}}{\mathrm{E}}\left[\mathrm{Ku}(1-\mathrm{T})+\mathrm{KdT}-\mathrm{R}_{\mathrm{F}}\right]$ \\
\hline$\beta_{\mathrm{L}}$ & $\beta_{L}=\beta u+\frac{D}{E}(\beta u-\beta d)+\frac{D}{E} \frac{T K d}{P_{M}}$ & $\beta_{\mathrm{L}}=\beta \mathrm{u}+\frac{\mathrm{D}}{\mathrm{E}}(\beta \mathrm{u}(1-\mathrm{T})-\mathrm{T} \beta \mathrm{d})$ \\
\hline WACC & $\mathrm{Ku}$ & $\mathrm{Ku}-\frac{\mathrm{D}\left(\mathrm{KuT}-\mathrm{Kd}+\mathrm{R}_{\mathrm{F}}\right)}{\mathrm{E}+\mathrm{D}}$ \\
\hline WACC $_{\mathrm{BT}}$ & $\mathrm{Ku}+\frac{\mathrm{DKdT}}{\mathrm{E}+\mathrm{D}}$ & $\mathrm{Ku}-\frac{\left.\mathrm{D}\left[(\mathrm{Ku}-\mathrm{Kd}) \mathrm{T}+\mathrm{R}_{\mathrm{F}}-\mathrm{Kd}\right)\right]}{\mathrm{E}+\mathrm{D}}$ \\
\hline VTS & 0 & $\mathrm{PV}\left[\mathrm{Ku} ; \mathrm{D}\left(\mathrm{KuT}+\mathrm{R}_{\mathrm{F}}-\mathrm{Kd}\right)\right]$ \\
\hline $\mathrm{ECF}_{\mathrm{t}} \| \mathrm{Ku}$ & $\mathrm{ECF}_{\mathrm{t}}-\mathrm{D}_{\mathrm{t}-1}\left[\mathrm{Ku}_{\mathrm{t}}-\mathrm{Kd}_{\mathrm{t}}(1-\mathrm{T})\right]$ & $\mathrm{ECF}_{\mathrm{t}}-\mathrm{D}_{\mathrm{t}-1}\left[\mathrm{Ku}_{\mathrm{t}}(1-\mathrm{T})+\mathrm{Kd}_{\mathrm{t}} \mathrm{T}-\mathrm{R}_{\mathrm{F}} \mathrm{t}\right.$ \\
\hline $\mathrm{FCF}_{\mathrm{t}} \| \mathrm{Ku}$ & $\mathrm{FCF}_{\mathrm{t}}$ & $\mathrm{FCF}_{\mathrm{t}}+\mathrm{D}_{\mathrm{t}-1}\left[\mathrm{Ku}_{\mathrm{t}} \mathrm{T}-\mathrm{Kd}_{\mathrm{t}}+\mathrm{R}_{\mathrm{Ft}}\right]$ \\
\hline $\mathrm{ECF}_{\mathrm{t}} \| \mathrm{R}_{\mathrm{F}}$ & $\begin{array}{c}\mathrm{ECF}_{\mathrm{t}}-\mathrm{D}_{\mathrm{t}-1}\left[\mathrm{Ku}_{\mathrm{t}}-\mathrm{Kd}_{\mathrm{t}}(1-\mathrm{T})\right]- \\
-\mathrm{E}_{\mathrm{t}-1}\left(\mathrm{Ku}_{\mathrm{t}}-\mathrm{R}_{\mathrm{Ft}}\right)\end{array}$ & $\begin{array}{c}\mathrm{ECF}_{\mathrm{t}}-\mathrm{D}_{\mathrm{t}-1}\left[\mathrm{Ku}_{\mathrm{t}}(1-\mathrm{T})+\mathrm{Kd}_{\mathrm{t}} \mathrm{T}-\mathrm{R}_{\mathrm{F}} \mathrm{t}\right. \\
-\mathrm{E}_{\mathrm{t}-1}\left(\mathrm{Ku}_{\mathrm{t}}-\mathrm{R}_{\mathrm{F}}\right)\end{array}$ \\
\hline $\mathrm{FCF}_{\mathrm{t}} \| \mathrm{R}_{\mathrm{F}}$ & $\mathrm{FCF}_{\mathrm{t}}-\left(\mathrm{E}_{\mathrm{t}-1}+\mathrm{D}_{\mathrm{t}-1}\right)\left(\mathrm{Ku}_{\mathrm{t}}-\mathrm{R}_{\mathrm{Ft}}\right)$ & $\begin{array}{c}\mathrm{FCF}_{\mathrm{t}}+\mathrm{D}_{\mathrm{t}-1}\left[\mathrm{Ku}_{\mathrm{t}} \mathrm{T}-\mathrm{Kd}_{\mathrm{t}}+\mathrm{R}_{\mathrm{F}}\right]- \\
-\left(\mathrm{E}_{\mathrm{t}-1}+\mathrm{D}_{\mathrm{t}-1}\right)\left(\mathrm{Ku}_{\mathrm{t}}-\mathrm{R}_{\mathrm{F}}\right)\end{array}$ \\
\hline
\end{tabular}

\begin{tabular}{|c|c|c|}
\hline & Modigliani-Miller & Practitioners' \\
\hline $\mathrm{Ke}$ & $\mathrm{Ke}=\mathrm{Ku}+\frac{\mathrm{D}}{\mathrm{E}}\left[\mathrm{Ku}-\mathrm{Kd}(1-\mathrm{T})-(\mathrm{Ku}-\mathrm{g}) \frac{\mathrm{VTS}}{\mathrm{D}}\right] *$ & $\mathrm{Ke}=\mathrm{Ku}+\frac{\mathrm{D}}{\mathrm{E}}\left(\mathrm{Ku}-\mathrm{R}_{\mathrm{F}}\right)$ \\
\hline$\beta_{\mathrm{L}}$ & $\beta_{L}=\beta u+\frac{D}{E}\left[\beta u-\beta d+\frac{T K d}{P_{M}}-\frac{V T S(K u-g)}{D_{M} P_{M}}\right] *$ & $\beta_{L}=\beta u+\frac{D}{E} \beta u$ \\
\hline WACC & $\frac{\mathrm{D} \mathrm{Ku}-(\mathrm{Ku}-\mathrm{g}) \mathrm{VTS}}{(\mathrm{E}+\mathrm{D})} *$ & $K u-D \frac{R_{F}-K d(1-T)}{E+D}$ \\
\hline WACC $_{\mathrm{BT}}$ & $\frac{\mathrm{DKu}-(\mathrm{Ku}-\mathrm{g}) \mathrm{VTS}+\mathrm{DTKd}}{\mathrm{E}+\mathrm{D}} *$ & $\mathrm{Ku}+\mathrm{D} \frac{\mathrm{Kd}-\mathrm{R}_{\mathrm{F}}}{\mathrm{E}+\mathrm{D}}$ \\
\hline VTS & $\mathrm{PV}\left[\mathrm{R}_{\mathrm{F}} ; \mathrm{T} \mathrm{D} \mathrm{R} \mathrm{R}_{\mathrm{F}}\right]$ & $\mathrm{PV}\left[\mathrm{Ku} ; \mathrm{T} \mathrm{D} \mathrm{Kd}-\mathrm{D}\left(\mathrm{Kd}-\mathrm{R}_{\mathrm{F}}\right)\right]$ \\
\hline $\mathrm{ECF}_{\mathrm{t}} \| \mathrm{Ku}$ & $\mathrm{ECF}_{\mathrm{t}}-\mathrm{D}_{\mathrm{t}-1}\left[\mathrm{Ku}_{\mathrm{t}}-\mathrm{Kd}_{\mathrm{t}}(1-\mathrm{T})-(\mathrm{Ku}-\mathrm{g}) \mathrm{VTS} / \mathrm{D}\right]^{*}$ & $E C F_{t}-D_{t-1}\left(K_{t}-R_{F t}\right)$ \\
\hline $\mathrm{FCF}_{\mathrm{t}} \| \mathrm{Ku}$ & $\mathrm{FCF}_{\mathrm{t}}+\mathrm{E}_{\mathrm{t}-1} \mathrm{Ku}+(\mathrm{Ku}-\mathrm{g}) \mathrm{VTS} *$ & $\mathrm{FCF}_{\mathrm{t}}+\mathrm{D}_{\mathrm{t}-1}\left[\mathrm{R}_{\mathrm{Ft}}-\mathrm{Kd}_{\mathrm{t}}(1-\mathrm{T})\right]$ \\
\hline $\mathrm{ECF}_{\mathrm{t}} \| \mathrm{R}_{\mathrm{F}}$ & $\begin{array}{c}\mathrm{ECF}_{\mathrm{t}}-\mathrm{D}_{\mathrm{t}-1}\left[\mathrm{Ku}_{\mathrm{t}}-\mathrm{Kd}_{\mathrm{t}}(1-\mathrm{T})-(\mathrm{Ku}-\mathrm{g}) \mathrm{VTS} / \mathrm{D}\right]- \\
-\mathrm{E}_{\mathrm{t}-1}\left(\mathrm{Ku}_{\mathrm{t}}-\mathrm{R}_{\mathrm{Ft}}\right)^{*}\end{array}$ & $\mathrm{ECF}_{\mathrm{t}}-\left(\mathrm{E}_{\mathrm{t}-1}+\mathrm{D}_{\mathrm{t}-1}\right)\left(\mathrm{Ku}_{\mathrm{t}}-\mathrm{R}_{\mathrm{F}} \mathrm{t}\right)$ \\
\hline $\mathrm{FCF}_{\mathrm{t}} \| \mathrm{R}_{\mathrm{F}}$ & $\begin{array}{c}\mathrm{FCF}_{\mathrm{t}}+\mathrm{E}_{\mathrm{t}-1} \mathrm{Ku}+(\mathrm{Ku}-\mathrm{g}) \mathrm{VTS}- \\
-\left(\mathrm{E}_{\mathrm{t}-1}+\mathrm{D}_{\mathrm{t}-1}\right)\left(\mathrm{Ku}_{\mathrm{t}}-\mathrm{R}_{\mathrm{Ft}}\right)^{*}\end{array}$ & $\begin{array}{c}\mathrm{FCF}_{\mathrm{t}}+\mathrm{D}_{\mathrm{t}-1}\left[\mathrm{R}_{\mathrm{Ft}}-\mathrm{Kd}_{\mathrm{t}}(1-\mathrm{T})\right]- \\
-\left(\mathrm{E}_{\mathrm{t}-1}+\mathrm{D}_{\mathrm{t}-1}\right)\left(\mathrm{Ku}_{\mathrm{t}}-\mathrm{R}_{\mathrm{Ft}}\right)\end{array}$ \\
\hline
\end{tabular}

* Valid only for growing perpetuities. 


\section{Appendix 2 (continued)}

\section{Equations common to all methods:}

$\mathrm{WACC}_{t}=\frac{\mathrm{E}_{\mathrm{t}-1} \mathrm{Ke}_{\mathrm{t}}+\mathrm{D}_{\mathrm{t}-1} \mathrm{Kd}_{\mathrm{t}}(1-\mathrm{T})}{\mathrm{E}_{\mathrm{t}-1}+\mathrm{D}_{\mathrm{t}-1}} \quad \mathrm{WACC}_{\mathrm{BT} t}=\frac{\mathrm{E}_{\mathrm{t}-1} \mathrm{Ke}_{\mathrm{t}}+\mathrm{D}_{\mathrm{t}-1} \mathrm{Kd}_{\mathrm{t}}}{\mathrm{E}_{\mathrm{t}-1}+\mathrm{D}_{\mathrm{t}-1}}$

\section{Relationships between cash flows:}

$\mathrm{ECF}_{\mathrm{t}}=\mathrm{FCF}_{\mathrm{t}}+\left(\mathrm{D}_{\mathrm{t}}-\mathrm{D}_{\mathrm{t}-1}\right)-\mathrm{D}_{\mathrm{t}-1} \mathrm{Kd}_{\mathrm{t}}(1-\mathrm{T})$

$\mathrm{CCF}_{\mathrm{t}}=\mathrm{FCF}_{\mathrm{t}}+\mathrm{D}_{\mathrm{t}-1} \mathrm{Kd}_{\mathrm{t}} \mathrm{T} \quad \mathrm{CCF}_{\mathrm{t}}=\mathrm{ECF}_{\mathrm{t}}-\left(\mathrm{D}_{\mathrm{t}}-\mathrm{D}_{\mathrm{t}-1}\right)+\mathrm{D}_{\mathrm{t}-1} \mathrm{Kd}_{\mathrm{t}}$

Cash flows $\backslash \mathrm{Ku}$ :

$\mathrm{ECF} \backslash \mid \mathrm{Ku}=\mathrm{ECF}_{\mathrm{t}}-\mathrm{E}_{\mathrm{t}-1}\left(\mathrm{Ke}_{\mathrm{t}}-\mathrm{Ku}_{\mathrm{t}}\right)$

$\mathrm{FCF} \backslash\left|\mathrm{Ku}=\mathrm{FCF}_{\mathrm{t}}-\left(\mathrm{E}_{\mathrm{t}-1}+\mathrm{D}_{\mathrm{t}-1}\right)\left(\mathrm{WACC}_{\mathrm{t}}-\mathrm{Ku} \mathrm{t}_{\mathrm{t}}\right)=\mathrm{CCF} \backslash\right| \mathrm{Ku}=\mathrm{CCF}_{\mathrm{t}}-\left(\mathrm{E}_{\mathrm{t}-1}+\mathrm{D}_{\mathrm{t}-1}\right)\left(\mathrm{WACC} \mathrm{BTt}_{\mathrm{t}}-\mathrm{Ku}_{\mathrm{t}}\right)$

Cash flows $\backslash \mathrm{R}_{\mathrm{F}}$ :

$\mathrm{ECF} \backslash \mid R_{\mathrm{F}}=\mathrm{ECF}_{\mathrm{t}}-\mathrm{E}_{\mathrm{t}-1}\left(\mathrm{Ke}_{\mathrm{t}}-\mathrm{R}_{\mathrm{Ft}}\right)$

$F C F\left\|R_{F}=F_{C F}-\left(E_{t-1}+D_{t-1}\right)\left(W A C C_{t}-R_{F t}\right)=C C F\right\| R_{F}=C_{C F}-\left(E_{t-1}+D_{t-1}\right)\left(W A C C_{B T t}-R_{F t}\right)$

$E C F \backslash\left|R_{F}=E C F \backslash\right| K u-E_{t-1}\left(K_{t}-R_{F t}\right)$

$F C F \backslash\left|R_{F}=F C F \backslash\right| K u-\left(E_{t-1}+D_{t-1}\right)\left(K u_{t}-R_{F t}\right)$

$\mathrm{FCF} \backslash|\mathrm{Ku}-\mathrm{ECF} \backslash| \mathrm{Ku}=\mathrm{D}_{\mathrm{t}-1} \mathrm{Ku} \mathrm{t}_{\mathrm{t}}-\left(\mathrm{D}_{\mathrm{t}}-\mathrm{D}_{\mathrm{t}-1}\right)$

$F C F|| R_{F}-E C F|| R_{F}=D_{t-1} R_{F t}-\left(D_{t}-D_{t-1}\right)$ 


\section{Appendix 3}

Valuation Equations According to the Main Theories when the Debt's Market Value (D) Is Not Equal to Its Nominal or Book Value (N)

This appendix contains the expressions of the basic methods for valuing companies by discounted cash flows when the debt's market value (D) is not equal to its nominal value (N). If the debt's market value (D) is not equal to its nominal value $(\mathrm{N})$, it is because the required return on debt $(\mathrm{Kd})$ is different from the cost of the debt $(\mathrm{r})$.

The interest paid in a period $t$ is: $I_{t}=N_{t-1} r_{t}$ The increase in debt in period $t$ is: $\Delta N_{t}=N_{t}-N_{t-1}$. Consequently, the debt cash flow in period $t$ is: $C F d=I_{t}-\Delta N_{t}=N_{t-1} r_{t}-\left(N_{t}-N_{t-1}\right)$.

Consequently, the value of the debt at $t=0$ is: $D_{0}=\sum_{t=1}^{\infty} \frac{N_{t-1} r_{t}-\left(N_{t}-N_{t-1}\right)}{\prod_{1}^{t}\left(1+K_{t}\right)}$

It is easy to show that the relationship between the debt's market value (D) and its nominal value $(\mathrm{N})$ is:

$\mathrm{D}_{\mathrm{t}}-\mathrm{D}_{\mathrm{t}-1}=\mathrm{N}_{\mathrm{t}}-\mathrm{N}_{\mathrm{t}-1}+\mathrm{D}_{\mathrm{t}-1} \mathrm{Kdt}-\mathrm{N}_{\mathrm{t}-1} \mathrm{r}_{\mathrm{t}}$

Consequently: $\Delta \mathrm{Dt}=\Delta \mathrm{Nt}+\mathrm{D}_{\mathrm{t}-1} \mathrm{Kdt}-\mathrm{N}_{\mathrm{t}-1} \mathrm{r}_{\mathrm{t}}$

The fact that the debt's market value (D) is not equal to its nominal value (N) affects several equations given in Section 1 of this paper. Equations [1], [3], [4], [6], [7], [9] and [10] continue to be valid, but the other equations change.

The expression of the WACC in this case is:

$$
\left[2^{*}\right] \mathrm{WACC}=\frac{\mathrm{E} \mathrm{Ke}+\mathrm{D} \mathrm{Kd}-\mathrm{N} \mathrm{r} \mathrm{T}}{\mathrm{E}+\mathrm{D}}
$$

The expression relating the ECF to the FCF is:

$$
\left[5^{*}\right] \mathrm{ECF}_{\mathrm{t}}=\mathrm{FCF}_{\mathrm{t}}+\left(\mathrm{N}_{\mathrm{t}}-\mathrm{N}_{\mathrm{t}-1}\right)-\mathrm{Nt}-1 \mathrm{rt}(1-\mathrm{T})
$$

The expression relating the CCF to the ECF and the FCF is:

\begin{tabular}{|c|c|c|c|}
\hline & Fernández (2004) & Damodaran (1994) & Practitioners' \\
\hline WACC & $\mathrm{Ku}-\frac{\mathrm{NrT}+\mathrm{DT}(\mathrm{Ku}-\mathrm{Kd})}{(\mathrm{E}+\mathrm{D})}$ & $\mathrm{Ku}-\frac{\mathrm{NrT}+\mathrm{D}\left[\mathrm{T}\left(\mathrm{Ku}-\mathrm{R}_{\mathrm{F}}\right)-\left(\mathrm{Kd}-\mathrm{R}_{\mathrm{F}}\right)\right]}{(\mathrm{E}+\mathrm{D})}$ & $\mathrm{Ku}-\frac{\mathrm{NrT}-\mathrm{D}\left(\mathrm{Kd}-\mathrm{R}_{\mathrm{F}}\right)}{(\mathrm{E}+\mathrm{D})}$ \\
\hline VTS & $\mathrm{PV}[\mathrm{Ku} ; \mathrm{DTKu}+\mathrm{T}(\mathrm{Nr}-\mathrm{DKd})]$ & $\mathrm{PV}\left[\mathrm{Ku} ; \mathrm{T} \mathrm{N} \mathrm{r}+\mathrm{DT}\left(\mathrm{Ku}-\mathrm{R}_{\mathrm{F}}\right)-\mathrm{D}\left(\mathrm{Kd}-\mathrm{R}_{\mathrm{F}}\right)\right]$ & $\mathrm{PV}\left[\mathrm{Ku} ; \mathrm{T} \mathrm{N} \mathrm{r}-\mathrm{D}\left(\mathrm{Kd}-\mathrm{R}_{\mathrm{F}}\right)\right]$ \\
\hline $\mathrm{FCF}_{\mathrm{t}} \| \mathrm{Ku}$ & $\begin{aligned} & \mathrm{FCF}_{\mathrm{t}}+\mathrm{D}_{\mathrm{t}-1} \mathrm{Ku}_{\mathrm{t}} \mathrm{T}+ \\
+ & \mathrm{T}\left(\mathrm{N}_{\mathrm{t}-1} \mathrm{r}_{\mathrm{t}}-\mathrm{D}_{\mathrm{t}-1} \mathrm{Kd}_{\mathrm{t}}\right)\end{aligned}$ & $\begin{array}{c}\mathrm{FCF}_{\mathrm{t}}+\mathrm{D}_{\mathrm{t}-1} \mathrm{Ku}_{\mathrm{t}} \mathrm{T}+\mathrm{T}\left(\mathrm{N}_{\mathrm{t}-1} \mathrm{r}_{\mathrm{t}}-\mathrm{D}_{\mathrm{t}-1} \mathrm{Kd}_{\mathrm{t}}\right)- \\
-\mathrm{D}_{\mathrm{t}-1}\left(\mathrm{Kd}_{\mathrm{t}}-\mathrm{R}_{\mathrm{Ft}} \mathrm{t}\right)(1-\mathrm{T})\end{array}$ & $\begin{array}{c}\mathrm{FCF}_{\mathrm{t}}+\mathrm{T}\left(\mathrm{N}_{\mathrm{t}-1} \mathrm{r}_{\mathrm{t}}-\mathrm{D}_{\mathrm{t}-1} \mathrm{Kd}_{\mathrm{t}}\right)+ \\
+\mathrm{D}_{\mathrm{t}-1}\left[\mathrm{R}_{\mathrm{Ft}}-\mathrm{Kd}_{\mathrm{t}}(1-\mathrm{T})\right]\end{array}$ \\
\hline
\end{tabular}

$$
\text { [8*] } \mathrm{CCF}_{\mathrm{t}}=\mathrm{ECF}_{\mathrm{t}}+\mathrm{CFd}_{\mathrm{t}}=\mathrm{ECF}_{\mathrm{t}}-\left(\mathrm{N}_{\mathrm{t}}-\mathrm{N}_{\mathrm{t}-1}\right)+\mathrm{N}_{\mathrm{t}-1} \mathrm{r}_{\mathrm{t}}=\mathrm{FCF}_{\mathrm{t}}+\mathrm{N}_{\mathrm{t}-1} \mathrm{r}_{\mathrm{t}} \mathrm{T}
$$


Appendix 3 (continued)

\begin{tabular}{|l|c|c|c|}
\hline & $\begin{array}{c}\text { Harris-Pringle (1985) } \\
\text { Ruback (1995) }\end{array}$ & Myers (1974) & Miles-Ezzell (1980) \\
\hline WACC & $\mathrm{Ku}-\frac{\mathrm{N} \mathrm{rT}}{(\mathrm{E}+\mathrm{D})}$ & $\mathrm{Ku}-\frac{\mathrm{VTS}(\mathrm{Ku}-\mathrm{Kd})+\mathrm{N} \mathrm{rT}}{(\mathrm{E}+\mathrm{D})}$ & $\mathrm{Ku}-\frac{\mathrm{N} \mathrm{rT}}{(\mathrm{E}+\mathrm{D})} \frac{1+\mathrm{Ku}}{1+\mathrm{Kd}}$ \\
\hline $\mathrm{VTS}$ & $\mathrm{PV}[\mathrm{Ku} ; \mathrm{T} \mathrm{N} \mathrm{r}]$ & $\mathrm{PV}[\mathrm{Kd} ; \mathrm{T} \mathrm{N} \mathrm{r}]$ & $\mathrm{PV}\left[\mathrm{Ku}_{\mathrm{t}} ; \mathrm{N}_{\mathrm{t}-1} \mathrm{r}_{\mathrm{t}} \mathrm{T}\right](1+\mathrm{Ku}) /(1+\mathrm{Kd})$ \\
\hline $\mathrm{FCF}_{\mathrm{t}}|| \mathrm{Ku}$ & $\mathrm{FCF}_{\mathrm{t}}+\mathrm{T} \mathrm{N}_{\mathrm{t}-1} \mathrm{r}_{\mathrm{t}}$ & $\mathrm{FCF}_{\mathrm{t}}+\mathrm{T} \mathrm{N} \mathrm{r}+\mathrm{VTS}(\mathrm{Ku}-\mathrm{Kd})$ & $\mathrm{FCF}+\mathrm{T} \mathrm{N} \mathrm{r}(1+\mathrm{Ku}) /(1+\mathrm{Kd})$ \\
\hline
\end{tabular}

Equations common to all the methods:

WACC and $\mathrm{WACC}_{\mathrm{BT}}$ :

$\mathrm{WACC}_{\mathrm{t}}=\frac{\mathrm{E}_{\mathrm{t}-1} \mathrm{Ke}_{\mathrm{t}}+\mathrm{D}_{\mathrm{t}-1} \mathrm{Kd}_{\mathrm{t}}-\mathrm{N}_{\mathrm{t}-1} \mathrm{r}_{\mathrm{t}} \mathrm{T}}{\left(\mathrm{E}_{\mathrm{t}-1}+\mathrm{D}_{\mathrm{t}-1}\right)}$

$$
\mathrm{WACC}_{\mathrm{BTt}}=\frac{\mathrm{E}_{\mathrm{t}-1} \mathrm{Ke}_{\mathrm{t}}+\mathrm{D}_{\mathrm{t}-1} \mathrm{Kd}_{\mathrm{t}}}{\left(\mathrm{E}_{\mathrm{t}-1}+\mathrm{D}_{\mathrm{t}-1}\right)}
$$

$\mathrm{WACC}_{\mathrm{BTt}}-\mathrm{WACC}_{\mathrm{t}}=\frac{\mathrm{N}_{\mathrm{t}-1} \mathrm{r}_{\mathrm{t}} \mathrm{T}}{\left(\mathrm{E}_{\mathrm{t}-1}+\mathrm{D}_{\mathrm{t}-1}\right)}$

Relationships between the cash flows:

$$
\begin{aligned}
& \mathrm{ECF}_{\mathrm{t}}=\mathrm{FCF}_{\mathrm{t}}+\left(\mathrm{N}_{\mathrm{t}}-\mathrm{N}_{\mathrm{t}-1}\right)-\mathrm{N}_{\mathrm{t}-1} \mathrm{r}_{\mathrm{t}}(1-\mathrm{T}) \quad \mathrm{CCF}_{\mathrm{t}}=\mathrm{FCF}_{\mathrm{t}}+\mathrm{N}_{\mathrm{t}-1} \mathrm{r}_{\mathrm{t}} \mathrm{T} \\
& \mathrm{CCF}_{\mathrm{t}}=\mathrm{ECF}_{\mathrm{t}}-\left(\mathrm{N}_{\mathrm{t}}-\mathrm{N}_{\mathrm{t}-1}\right)+\mathrm{N}_{\mathrm{t}-1} \mathrm{r}_{\mathrm{t}}
\end{aligned}
$$




\section{Appendix 4}

\section{Dictionary}

$B d=$ Beta of debt

$\beta_{L}=$ Beta of levered equity

$B \mathrm{u}=$ Beta of unlevered equity $=$ beta of assets

$\mathrm{D}=$ Value of debt

$\mathrm{E}=$ Value of equity

Ebv $=$ Book value of equity

$\mathrm{ECF}=$ Equity cash flow

$\mathrm{EP}=$ Economic profit

$\mathrm{EVA}=$ Economic value added

$\mathrm{FCF}=$ Free cash flow

$\mathrm{g}=$ Growth rate of the constant growth case

$\mathrm{I}=$ Interest paid

$\mathrm{Ku}=$ Cost of unlevered equity (required return on unlevered equity)

$\mathrm{Ke}=$ Cost of levered equity (required return on levered equity)

$\mathrm{Kd}=$ Required return on debt $=$ cost of debt

$\mathrm{N}=$ Book value of the debt

NOPAT $=$ Net operating profit after tax $=$ profit after tax of the unlevered company

PAT $=$ Profit after tax

$\mathrm{PBT}=$ Profit before tax

$\mathrm{P}_{\mathrm{M}}=$ Market premium $=\mathrm{E}\left(\mathrm{R}_{\mathrm{M}}-\mathrm{R}_{\mathrm{F}}\right)$

$\mathrm{PV}=$ Present value

$\mathrm{r}=$ Cost of debt

$\mathrm{R}_{\mathrm{F}}=$ Risk-free rate

$\mathrm{T}=$ Corporate tax rate

VTS = Value of the tax shield

$\mathrm{Vu}=$ Value of equity in the unlevered company

WACC $=$ Weighted average cost of capital

WACC $_{\text {BT }}=$ Weighted average cost of capital before taxes

$\mathrm{WCR}=$ Working capital requirements $=$ net current assets 


\section{References}

Arditti, F.D. and H. Levy (1977), "The Weighted Average Cost of Capital as a Cutoff Rate: A Critical Examination of the Classical Textbook Weighted Average," Financial Management (Fall), pp. 24-34.

Arzac, E.R and L.R. Glosten (2005), “A Reconsideration of Tax Shield Valuation,” European Financial Management, 11/4, pp. 453-461.

Cooper, I. A. and K. G. Nyborg (2006), "The Value of Tax Shields IS Equal to the Present Value of Tax Shields," Journal of Financial Economics, 81, pp. 215-225.

Copeland, T.E., T. Koller and J. Murrin (2000), "Valuation: Measuring and Managing the Value of Companies," Third edition, New York: Wiley.

Damodaran, A. (1994), “Damodaran on Valuation,” John Wiley and Sons, New York.

Fernández, P. (2002), "Valuation Methods and Shareholder Value Creation,” Academic Press.

Fernández, P. (2004), "The value of tax shields is NOT equal to the present value of tax shields," Journal of Financial Economics, Vol. 73/1 (July), pp. 145-165.

Fernández, P. (2006), “A More Realistic Valuation: APV and WACC with constant book leverage ratio," SSRN Working Paper no. 946090.

Harris, R.S. and J.J. Pringle (1985), "Risk-Adjusted Discount Rates Extensions Form the Average-Risk Case,” Journal of Financial Research (Fall), pp. 237-244.

Inselbag, I. and H. Kaufold (1997), "Two DCF Approaches for Valuing Companies under Alternative Financing Strategies (and How to Choose Between Them)," Journal of Applied Corporate Finance (Spring), pp. 114-122.

Kaplan, S. and R. Ruback (1995), "The Valuation of Cash Flow Forecasts: An Empirical Analysis," Journal of Finance, Vol 50, No 4, September.

Lewellen, W.G. and D.R. Emery (1986), "Corporate Debt Management and the Value of the Firm,” Journal of Financial Quantitative Analysis (December), pp. 415-426.

Luehrman, T. A. (1997), "What's It Worth: A General Manager's Guide to Valuation," and "Using APV: A Better Tool for Valuing Operations," Harvard Business Review, (MayJune), pp. 132-154.

Miles, J.A. and J.R. Ezzell (1980), "The Weighted Average Cost of Capital, Perfect Capital Markets and Project Life: A Clarification," Journal of Financial and Quantitative Analysis (September), pp. 719-730.

Miles, J.A. and J.R. Ezzell (1985), "Reequationing Tax Shield Valuation: A Note," Journal of Finance, Vol XL, 5 (December), pp. 1485-1492.

Miller, M. H. (1977), “Debt and Taxes,” Journal of Finance (May), pp. 261-276.

Modigliani, F. and M. Miller (1958), "The Cost of Capital, Corporation Finance and the Theory of Investment," American Economic Review 48, 261-297. 
Modigliani, F. and M. Miller (1963), "Corporate Income Taxes and the Cost of Capital: A Correction,” American Economic Review (June), pp. 433-443.

Myers, S.C. (1974), "Interactions of Corporate Financing and Investment Decisions Implications for Capital Budgeting," Journal of Finance (March), pp. 1-25

Ruback, R. S. (1995), “A Note on Capital Cash Flow Valuation,” Harvard Business School, 9-295-069.

Ruback, R. (2002), "Capital Cash Flows: A Simple Approach to Valuing Risky Cash Flows," Financial Management, 31, pp. 85-103.

Tham, J. and I. Vélez-Pareja (2001), "The Correct Discount Rate for the Tax Shield: the N-period Case,” SSRN Working Paper. 